\title{
Chapter 2 \\ The Road from Prosperity into the Crisis: The Long Cycle of Post-War Economic, Social and Political Development
}

\author{
Stephan Schulmeister
}

\begin{abstract}
This chapter provides an empirically founded reconstruction of the long road of (Western) societies into the present crisis as a background for the different studies carried out as part of the Jean Monnet Network "Crisis-Equity-Democracy for Europe and Latin America".
\end{abstract}

\section{Introduction and Overview}

This chapter addresses the key puzzle of post-war economic development: until the 1970s, production, trade and employment grew strongly and steadily, in the global economy as well as in the different regions; since then, however, economic growth has been declining over the long run and has become unstable over the short and medium run. At the same time, the differences in economic dynamics have been rising across continents and regions: Latin America and - to a lesser extent - Africa were hit by debt crises in the early 1980s and late 1990s and by the instability of commodities prices, whereas the economies in (East) Asia have been performing strongly, in particular in China.

The difference in economic performance between the 1950s and 1960s the subsequent crisis phase is the more puzzling as only the second phase was shaped by basic technological innovations (microelectronics, robotics, internet, biotechnology, nanotechnology) which - according to mainstream economics - should have accelerated economic growth. Market liberalization should have had the same effect as financial markets and labour markets were highly regulated in the 1950s and 1960s. In the prosperity phase, the welfare state was built up strongly, yet the public debt declined relative to GDP, whereas the opposite developments took place over the subsequent decades. All these facts stay in contrast to conventional (equilibrium) theory. An empirically founded reconstruction of the long road of (Western)

\footnotetext{
S. Schulmeister $(\bowtie)$

University of Vienna, Wien, Austria

e-mail: stephan.schulmeister@wifo-pens.at
} 
societies into the present crisis provides the background for the different studies carried out as part of the Jean Monnet Network "Crisis-Equity-Democracy for Europe and Latin America". A first sketch of the systemic causes of the long postwar cycle is as follows.

Understanding the main causes of the Great Depression - financial instability, austerity policies and protectionism - provided the economic guidelines for the prosperity phase: the incentive conditions directed the capitalist "core energy", i.e. striving for profits, to activities in the real economy. Stable dollar exchange rates, stable commodity prices, interest rates below the rate of economic growth and "sleeping" stock markets (at least in Europe) rendered financial speculation unprofitable and raised the profitability of investment, production and trade in the real economy at the same time. In addition, building up the welfare state strengthened confidence of households, reduced income inequality and fostered the steady expansion of consumption. This "real-capitalist" system was based on the theory of John M. Keynes which called not only for an economically active government but also for stabilizing financial markets. The "European Social Model" combined real-capitalist incentive conditions with a strong welfare state (also the Cold War called for a "social capitalism"): market and state, competition and cooperation, entrepreneurship and trade unionism, and individual self-interest and social coherence were regarded as complementary. The success of real capitalism laid the ground for its own decline: Over the 1960s, full employment and the expanding welfare state shifted power from business to unions. The latter enforced more employee participation as well as a redistribution in favour of wages. The leftist "Zeitgeist" strengthened social-democratic parties. In addition, the environmental movement ("Club of Rome") denounced the capitalist growth model as unsustainable. All these developments together caused (big) business to turn towards the neoliberal ideology which promised disciplining trade unions, weakening the welfare state and establishing a truly free market economy.

Friedrich A. von Hayek, the great antipode of Keynes in the debates over the world depression in the 1930s, had begun to plan a counter-movement against Keynesianism already after his "defeat" caused by the success of Keynes' General Theory (1936). Hayek's book The Road to Serfdom (1944) provided the ideological fundament of the neoliberal movement. In 1947, Hayek founded the Mont Pelerin Society as neoliberal network of outstanding economists ("original thinkers"); intellectuals, in particular journalists ("second-hand dealers in ideas"); and wealthy people as financiers of university chairs or think tanks. During the 1950s and 1960s, the "original thinkers" worked on the theoretical foundation of their vision of a "free market economy" - from Friedman's "proof" of the impossibility of destabilizing financial speculation (1953) or Buchanan's "public-choice approach" of analysing politics as a purely egoistic business of politicians to Friedman's theory of a "natural rate of unemployment" (1968) and Robert Lucas' concept of "rational expectations" (1972). These theories legitimated the offensive against the welfare state, trade unions and financial market regulations and got rising support from "industrial capitalists" (threatened by the rising power of unions) as well as from "finance capitalists" (threatened by rising inflation). 
The road into the present crisis began with the breakdown of the Bretton-Woods system between 1971 and 1973: the dollar lost 25\% of its value; OPEC reacted with the first oil price "shock" in 1973. This sequence repeated itself between 1976 and 1979 , leading to the second oil price "shock". Both "shocks" triggered two recessions and a strong acceleration of inflation. Neoliberal "original thinkers" took the coincidence of rising unemployment and rising inflation as disprove of Keynesian macroeconomics - even though their recommendations had contributed to this coincidence ("battle over the Phillips curve"). By the late 1970s, monetary policy began to fight inflation through raising interest rates like never before, far above the rate of economic growth. As this policy was most pronounced in the USA, the dollar almost doubled its value between 1980 and 1985, thereby appreciating the burden of international dollar debts: in 1982, the debt crisis of Latin America broke out. Within a decade, the economic system in the West was transformed from "real capitalism" to "finance capitalism", guided by the neoliberal "navigation map": the volatility of exchange rates and commodities prices, booming stock prices as well as a positive interest-growth differential shifted activities of non-financial business towards financial investments, facilitated by innovations like financial derivatives. The financial sector gradually transformed itself from a sector servicing the real economy to the dominant sector in the overall economy.

Neoliberal theories also legitimized policies against trade unions and the welfare state, first adopted in Chile after the military coup in 1973 and then in the UK and the USA where Margaret Thatcher and Ronald Reagan came to power in 1979 and 1980, respectively. Over the 1980s, high dollar interest and rising dollar exchange rates dampened the real economy in the USA strongly. Hence, monetary policy gave up monetarism and has been following an anti-cyclical course since Alan Greenspan became chairman of the Fed in 1987. Since Bill Clinton became US president in 1992, also fiscal policy has been conducted in an increasingly active, counter-cyclical manner. In other words, since the early 1990s, macroeconomic policy in the USA has been following a "trivial Keynesian" course. At the same time, economic policy in the EU gave up the Keynesian target of full employment and of social security through a comprehensive welfare state and began to follow neoliberal guidelines.

The main reason for this (gradual) change was the following. Finance-capitalist incentive conditions had caused the public debt to rise stronger in Europe than in the USA since financing the welfare state necessitates full employment. In the early 1990s, policy in the EU began to fight these "twin problems" through restrictive fiscal policy based on rules (Maastricht criteria, fiscal compact) and through labour market deregulation: the number of atypical jobs rose steadily (comprising nowadays roughly one third of overall jobs in the EU), unemployment benefits and social transfers in general have been cut, and the confidence in the welfare state got weaker. At the same time, speculative activities in financial markets boomed like never before, contributing to the rise in income and wealth inequality. After the stock market crash of 2000/2002, stock prices, house prices and commodity prices boomed simultaneously. The three "bull markets" tilted in 2007/2008 into three "bear markets", causing the biggest wealth devaluation since 1929 (the last time when these asset prices declined simultaneously). 
The systemic character of the financial crisis of 2008 and, hence, of the subsequent rise of unemployment and the public debt could not be recognized through the lens of "neoliberal glasses": after saving the banking sector and stimulating the economy in the crisis year 2009, austerity policy in the EU was again intensified, in particular in Southern Europe. Speculation on the bankruptcy of these states, first against Greece, then against Portugal, Spain and Italy, had caused interest rates to rise tremendously. Looking for a "save haven", investors drove up prices of government bonds of Germany and the other "good" countries. The related decline in interest rates in the "North" and rising interest in the "South" intensified the tensions within the European Monetary Union (EMU) and endangered its existence. In 2012, the ECB turned to an extremely loose monetary policy through lowering the key interest rate to zero and through buying government bonds. This policy caused bond prices to boom like never before and strengthened also the stock bull market which had already taken off in spring 2009. In addition, house prices have been rising strongly, this time not only in the USA and in the UK but also in continental Europe. Hence, the potential for a new simultaneous wealth devaluation has been built up in recent years. Austerity policies, on the one hand, and booming financial wealth, on the other hand, have increased inequality, strengthening the feelings of bitterness, uncertainty and fear of the future not only on behalf of the underprivileged but also of middle class people. Populists address both groups, promise "social warmth" within the own nation and direct their feelings against scapegoats of all types: against "the" globalisation, "the" EU, "the" system as well as "the" Greeks or "the" foreigners - in recent years in particular against refugees.

Whereas the prosperity phase had come to an end due to the success of real capitalism and the related shift in power in favour of trade unions and leftist parties, the crisis phase comes to an end due to the failure of finance capitalism and the related meltdown of wealth (in the next financial crisis) as well as the growing frustration of the "non-elites" in society. The above hypothesis about the driving forces of postwar development implies that there operates an interaction between economic theories and reality. On the one hand, theories serve as "navigation maps" thereby changing reality and leading occasionally into crises (as in the 1930s). On the other hand, new theories emerge in reaction to these crises, guiding economic development into new directions (as in the 1950s and 1960s).

\section{Framework Conditions and Economic Performance of Western Capitalism During the 1960s and 1970s}

Over the 1950s and 1960s, an active policy aiming at full employment, stable economic growth and social coherence together with stable exchange rates, commodity prices and interest rates (below the rate of economic growth) channelled striving for profits towards entrepreneurial activities in the real sphere of the economy. Under these real-capitalist incentive conditions, the economies of industrial countries grew strongly and steadily. For several reasons, this development was particularly 
pronounced in Western Europe. First, the reconstruction after WWII promoted investment and production. Second, building up the welfare state strengthened the confidence of households and, hence, their consumption. Third, trade liberalization and the integration process promoted trade in Europe stronger than elsewhere (the EEC and the EFTA were founded in 1957 and 1960, respectively).

Over the 1950s, the rate of unemployment had fallen steadily. In 1960, it amounted in Western Europe to only $1.8 \%$ on average and fluctuated slightly around 2\% until 1974 (Fig. 2.1). The welfare state was enlarged and the infrastructure improved. Both activities strengthened and stabilized economic growth so that the public debt was declining continuously from almost 70\% of GDP in the early 1950s to less than $40 \%$ in the early 1970s (Fig. 2.1).

Against the background of historical experience, this performance appeared as "economic miracle". However, it was just the result of coherent framework conditions: liberalizing goods markets and keeping financial markets regulated fostered activities in the real economy for two reasons. First, the costs of financing investment, production and trade were low and stable. Second, financial speculation was unprofitable. At the same time, building up the welfare state strengthened confidence and fairness in society. In other words, the strength of the European Social Model consisted in providing room for individual, self-interested "expansion" in the real economy through competition in liberalized goods markets, combined with strengthening social coherence through the welfare state ("institutionalized solidarity").

Promoting activities in the real economy through competition in goods markets combined with cooperative strategies in politics shaped economic development also at the global level: international trade was liberalized in several GATT rounds; transnational cooperation was strengthened through the Marshall plan, through development aid, through the activities of The World Bank and the International Monetary Fund as well as through the international monetary system. Until 1971, the dollar remained stable vis-à-vis the other reserve currencies contributing to the (relative) stability of commodity prices and to stable growth of world production - it fluctuated just between $4 \%$ and $6 \%$ per year (Fig. 2.2).

The success of the real-capitalist system, in particular when combined with a comprehensive welfare state, slowly changed the distribution of income and power in society and prepared the ground for the neoliberal "counter-offensive". Over the 1950s, a (tacit) deal between entrepreneurs and unions had prevailed: the latter accepted the dispositive power of the entrepreneurs as "bosses" and got "in exchange" more jobs. This deal came to an end once full employment was reached. Now, unions called for (more) employee participation and in particular for redistribution in favour of wages. Supported by permanent full employment, strike activities roughly tripled between 1965 and 1968 (particularly in Italy, France and the UK), enforcing to a large extent the fulfilling of the unions' demands: wages rose much faster than labour productivity; the wage share in nominal GDP increased over the 1960s like never before (Fig. 2.1).

Also ideological developments raised the concerns of industrialists about the long-term consequences of full employment and an expanding welfare state: in 

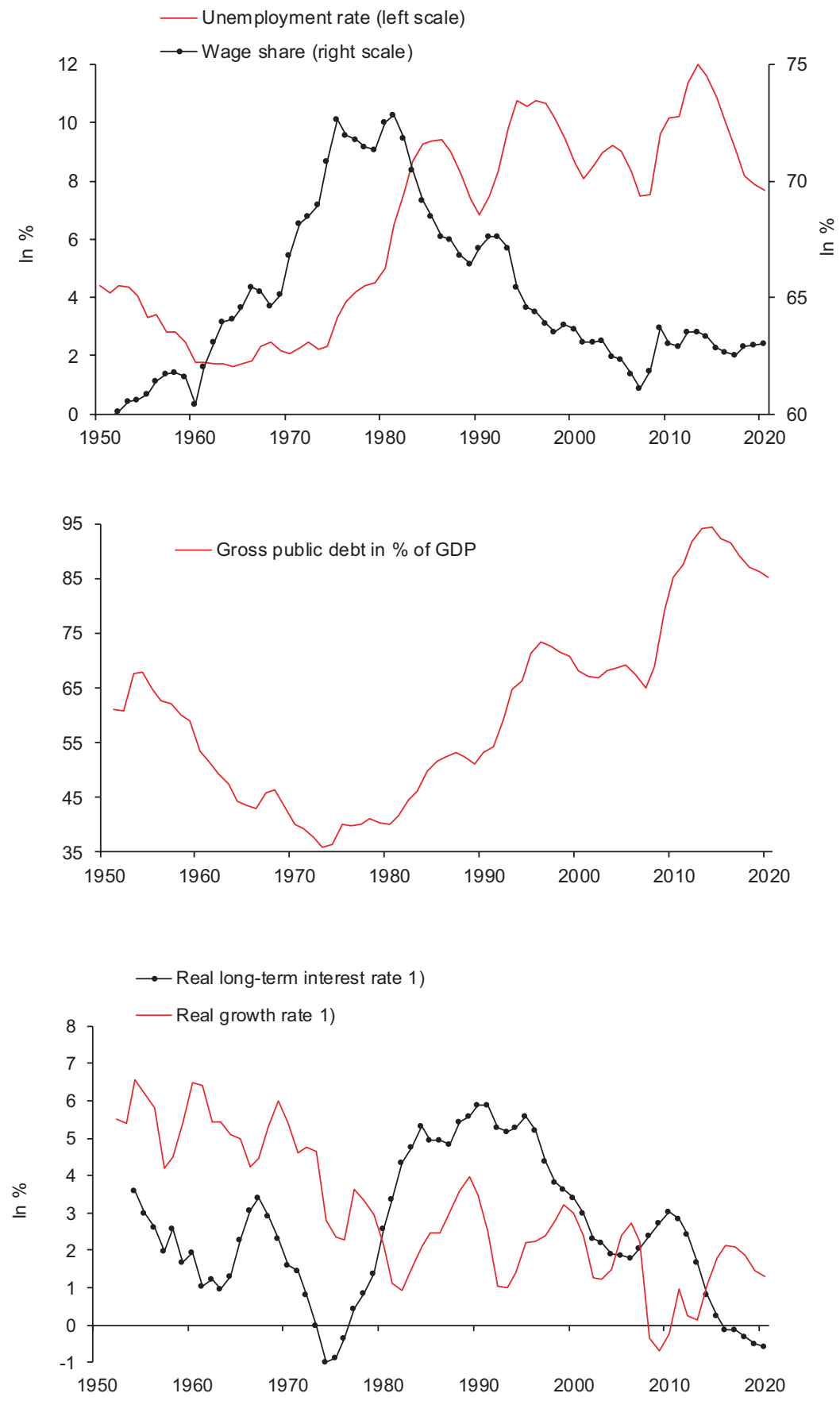

Fig. 2.1 Long-term economic development in Western Europe. 1) 3-year moving average. (Source: OECD, Eurostat, IMF) 


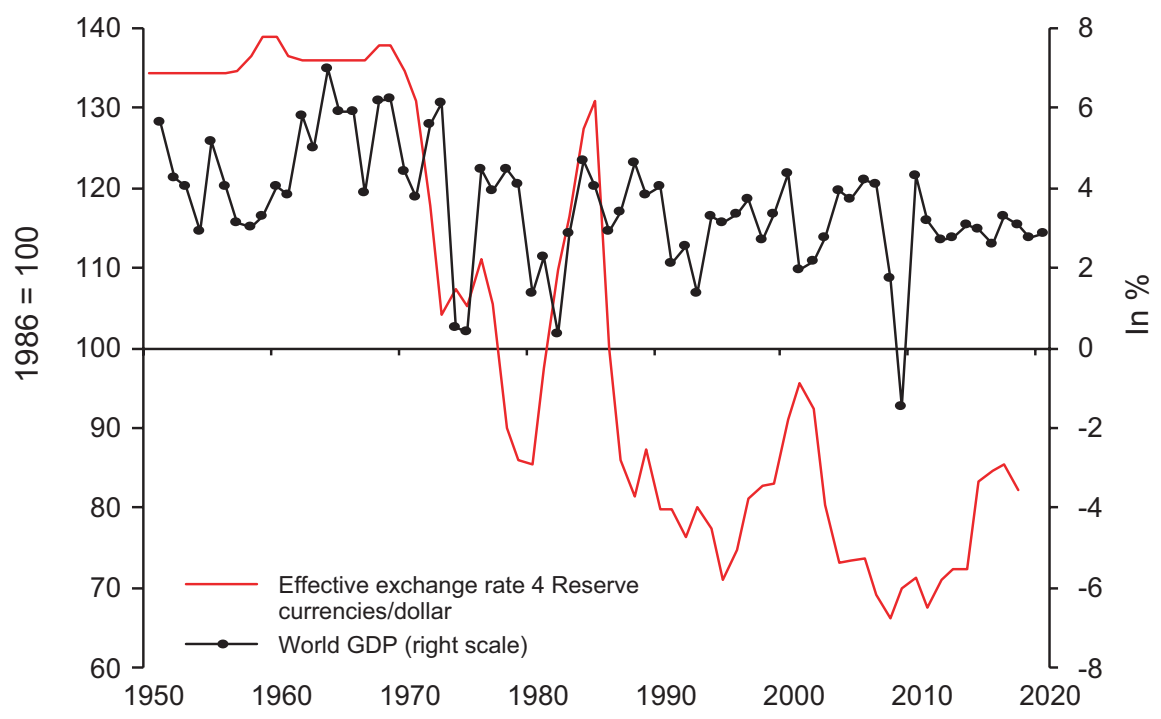

Fig. 2.2 Dollar exchange rate and the global economic growth. (Source: IMF, WIFO)

the second half of the 1960s, most intellectuals turned to the left (the students' protests in 1968 and the often sympathetic reports in the media were clear indicators of these changes). The left "Zeitgeist" strengthened social-democratic parties (Willy Brandt became chancellor in Germany in 1969, Bruno Kreisky in Austria in 1970). The "Club of Rome" criticized the resource-wasting capitalism ("The Limits to Growth", 1972) which appeared as the ultimate cause of global pollution. In the USA, industrialists became also concerned about the negative impact of the Bretton Woods system. Over the 1960s, the US economy lost almost permanently export market shares to Europe and Japan. Yet, the USA would never be able to devalue its currency due to its role as anchor of the Bretton Woods rules (the original dollar exchange rates had been "fair" due to the advantage of the US economy after WWII but became progressively overvalued due to the catching-up of other industrial countries, in particular Germany and Japan). The confidence in the exchange rate system got weaker also in the rest of the world since the USA abused its role as "world banker" through "dollar exports", in part for financing the Vietnam War. When the French president De Gaulle asked his central bank to have dollar claims converted into gold in 1967, the USA refused to do so. This decision made it clear that the USA would not stick to the gold convertibility of the dollar. ${ }^{1}$ In addition, inflation began to rise in the 1960 s, caused by persistently high economic growth and the related wage-price spiral. The acceleration of

\footnotetext{
${ }^{1}$ For the fundamental shortcoming of the Bretton Woods system, e.g. the double role of the dollar as standard currency of the world economy and as national currency of the USA, see Schulmeister (2000).
} 
inflation was particularly pronounced in the USA, to a large extent due to rising expenditures for the Vietnam War.

All these developments together rendered the neoliberal ideology (mainly in the form of monetarism) progressively more attractive for wealthy people. It promised to weaken trade unions and the welfare state, to fight leftist political movements, to get rid of the system of fixed exchange rates and to reduce inflation - the latter was particularly important for owners of big financial wealth which had grown strongly during the prosperity phase. For all these promises, neoliberal "original thinkers" had produced theoretical foundations, from Hayek's "The Road to Serfdom" (1944) or Friedman's "The Case for Flexible Exchange Rates" (1953) to his "The Role of Monetary Policy" (1968) which based an attack on full employment policy on his concept of a "natural rate of unemployment" (see section "Public Finances Under Real-Capitalist and Finance-Capitalist Conditions").

\section{Systemic Changes in Global Capitalism Since the 1970s and Their Impact}

The support of "big business" alone would not have been sufficient to make neoliberalism the most influential ideology of past decades because its call for weakening the welfare state as well as trade unions was not popular, certainly not among most European citizens. Therefore, the advance of neoliberalism took place "through the backdoor" of liberalizing financial markets: letting the system of pegged exchange rates collapse with the intention to weaken the dollar, strengthened by an expansive monetary policy, produced the expectation of a dollar depreciation which was then brought about through the respective speculative transactions. Over the 1970s, two dollar depreciations triggered two oil price "shocks", followed by two recessions and a rise in inflation, unemployment and the public debt.

These problems were then "cured" through neoliberal "recipes", e.g. "structural reforms", like (further) deregulating financial markets, weakening labour protection, dampening real wages, cutting social expenditures, raising interest rates and restricting the room for manoeuvre of fiscal and monetary policy through rules. These "therapies" worsened the "disease" which in turn called for increasing the "dose". In this way, the economic regime was transformed from a realcapitalist into a finance-capitalist system. The most important steps of this process were as follows.

In August 1971, the USA let the system of fixed exchange rates collapse (Figs. 2.2 and 2.3): during the subsequent bear market, the dollar lost $25 \%$ of its value vis-àvis the other SDR currencies (DM, franc, pound, yen). This development hit those countries most which exported exclusively crude oil, priced and paid in dollars: the OPEC countries in the Middle East. In October 1973, OPEC took advantage of the Yom Kippur War to fight back by putting through a tripling of crude oil prices (Fig. 2.3; the oil boycott served as bluff). The first "oil price shock" led into the first post-war recession in all industrial countries. As a consequence, not only inflation 


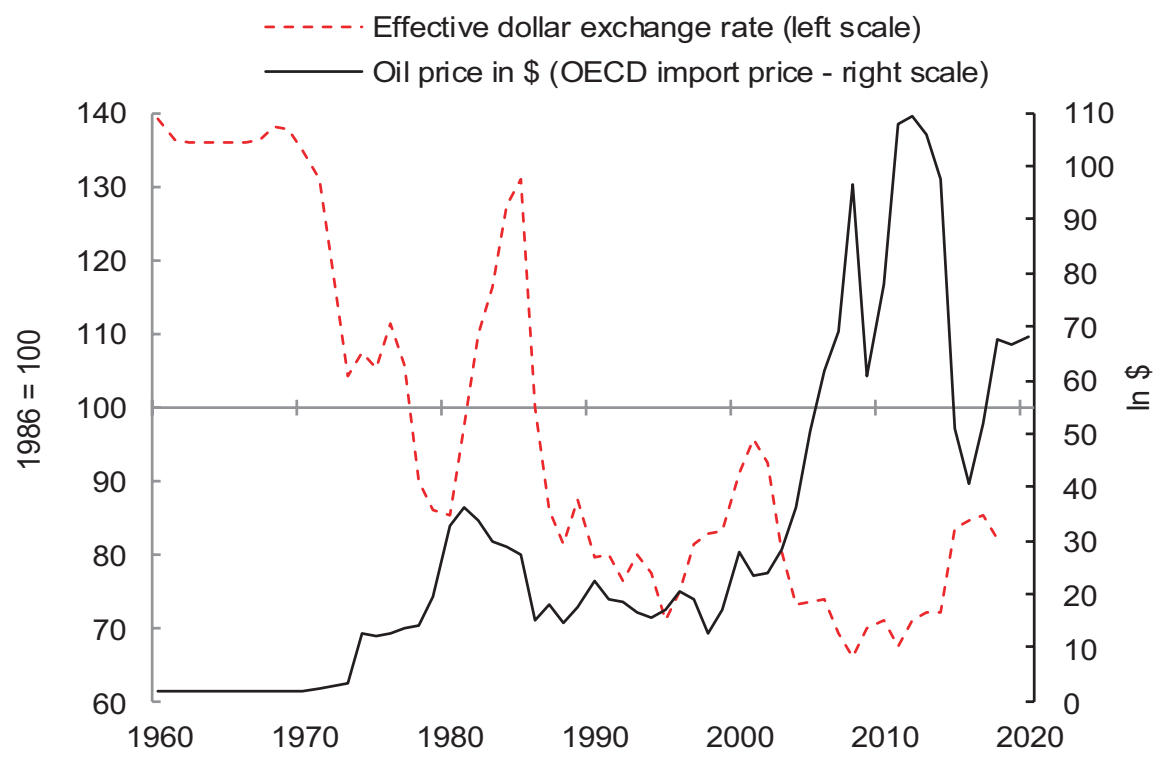

Fig. 2.3 Dollar exchange rate and oil price fluctuations. (Source: OECD, IMF)

but also unemployment rose significantly. This constellation was then taken as disprove of the Phillips curve and, hence, of Keynesian economics altogether (see below). In a second bear market, the dollar lost again $25 \%$ of its value between 1976 and 1979, leading to the second "oil price shock" in 1979 (again, OPEC took advantage of political turbulences like the coming to power of the Ayatollahs). It was again followed by a recession.

Since 1972 , the oil price had risen by a factor of 11 . The inflationary pressure spilled over to the prices of manufactures. As a consequence, the price level in overall world trade almost quadrupled during the 1970s (Fig. 2.4). The inverse development of the dollar exchange rate and world trade prices is, however, also due to the conversion of manufactures prices from the different national currencies into dollars. This statistical effect is of enormous economic importance: as most international debts (in particular of developing countries) are held in dollars, any persistent dollar depreciation is associated with negative real interest rates (approximated as difference between the nominal dollar rate - LIBOR - and the annual changes in world trade prices in dollar terms).

To put it concretely, exports of non-US countries to countries other than the USA earned DM, yen, etc. whose dollar value rose strongly over the 1970s. In particular, the "tiger economies" of that decade like Mexico, Argentina and Brazil took advantage of this valuation effect: they incurred more and more dollar debts to finance their import surplus (which helped industrialized countries struggling with two "oil price shocks"). This behaviour seemed rational as the falling dollar depreciated dollar debts. At the same time, the "petro dollars" of oil exporters, deposited in London, were "recycled", mainly to Latin American countries. 

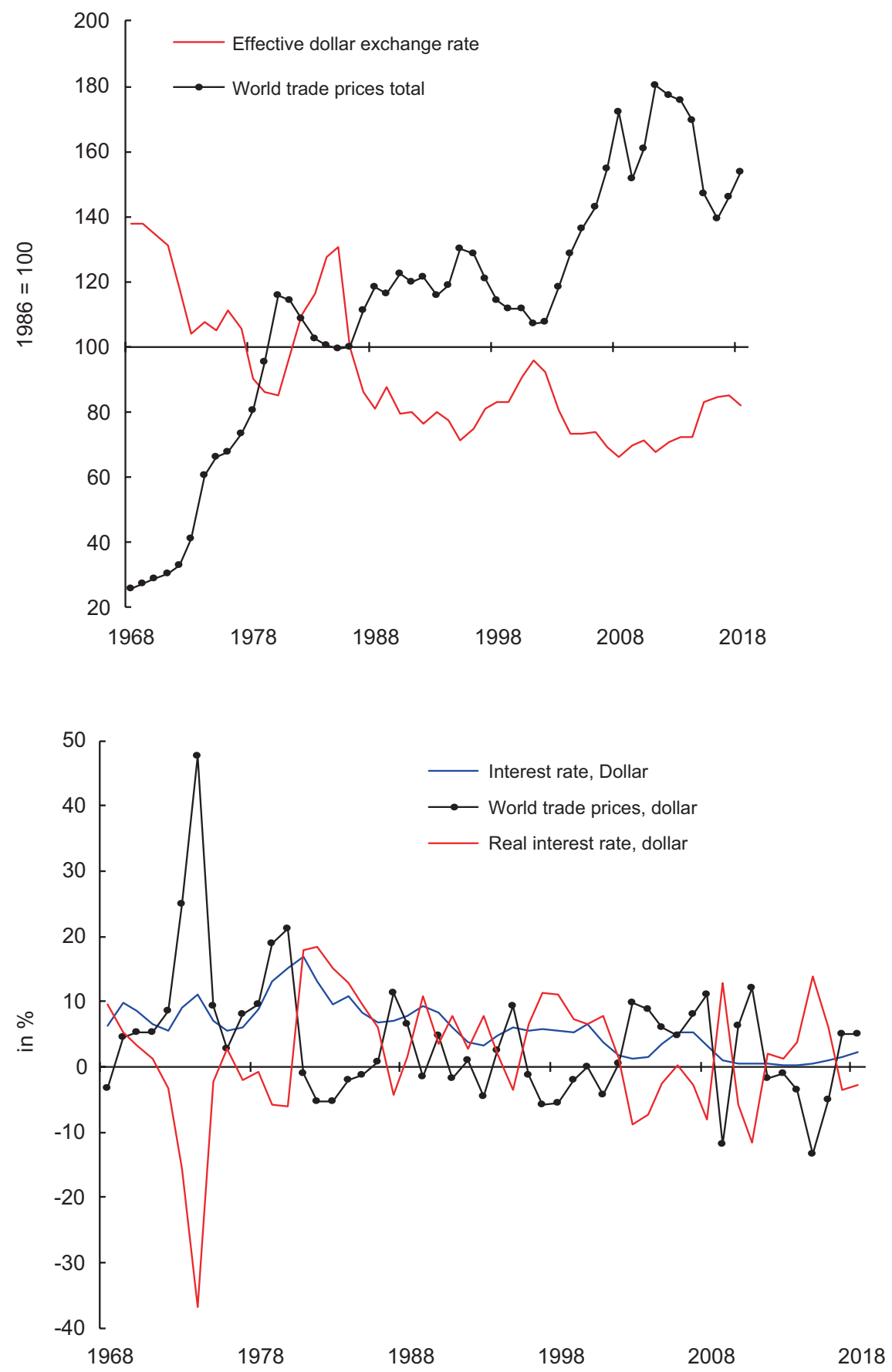

Fig. 2.4 Dollar exchange rate, world inflation and the real interest on a dollar debt. ${ }^{1}$ Vis-a-vis DM, pound, franc, yen. (Source: IMF, WIFO) 
As reaction to the acceleration of inflation in the 1970s, monetary policy increased interest rates like never before, most strongly in the USA (Fig. 2.4). ${ }^{2}$ Hence, traders expected an appreciation of the dollar (also because it had become strongly undervalued) which finally took off when Ronald Reagan was elected president of the USA in November 1980. Over the following 5 years, the strongest dollar bull market ever took place (Fig. 2.3). It appreciated international dollar debts, which Latin American (but also African) countries had accumulated during the 1970s under completely different conditions: between 1979 and 1981, the real interest on an international dollar debt jumped from $-6 \%$ to $+18 \%$ (Fig. 2.4). One year later, the international debt crisis broke out, which dampened the real economy in not only in these countries but in Latin America as a whole for more than a ("lost") decade. The increasing overvaluation of the dollar caused the bull market to tilt in 1985 again into a bear market. Until 1995, the dollar lost almost 50\% of its value, providing relief for international dollar debtors (Figs. 2.3 and 2.4): dollar prices in world trade picked up and, the real interest fell between 1985 and 1987 by almost $14 \%$ points.

Over the 1990s, the economic performance of the USA improved relative to Europe and Japan, due to the undervaluation of the dollar and the expansionary policy of the Clinton administration. In 1995, the second dollar bull market took off: world trade prices started to fall, the real interest on an international dollar debt jumped from $-3.4 \%$ to $+11.3 \%$ (Fig. 2.4). As a consequence, the booming economies in East Asia, which had financed their rising current account deficits through dollar credits, slid into a liquidity crisis in 1997/1998. ${ }^{3}$ The crisis then spilled over to Russia and Brazil. Both countries had - partly successfully - attempted to curb inflation through fixing the exchange rate of their respective currencies vis-à-vis the dollar. As long as the inflation in these countries was significantly higher than in the USA, nominal interest rates in Russia and Brazil, respectively, exceeded dollar rates. Speculators tried to profit from this differential through short-term capital inflows in both countries. As the dollar appreciated more and more, and, hence, also the rouble and the real, confidence in the pegged exchange rate vanished, capital flew out and forced a massive depreciation of both currencies. As an indirect consequence of the depreciation of the Brazilian real by roughly $60 \%$, also the currency board of Argentina collapsed in 2002.

Between 2002 and 2007, the dollar exchange rate again declined strongly (Fig. 2.3). This bear market induced a strong rise in world trade prices. As a consequence, interest rates on an international dollar debt became negative again,

\footnotetext{
${ }^{2}$ This policy was in line with monetarist theory and with the "trivial Keynesian" IS/LM approach. However, by raising interest rates, one does not specifically dampen inflation but the economy as a whole (which will then also reduce inflation). Such a strategy raises interest payments and, hence, production costs due to the interest rate accelerator: If, e.g. the interest rate rises from $5 \%$ to $8 \%$, interest payments rise by $60 \%$ (in case of bank credits at flexible rates).

${ }^{3}$ The "tiger economies" ran out of dollar liquidity to service their dollar debts. As their production structure was much better than that of Latin American countries in the early 1980s, they could overcome the crisis rather fast.
} 


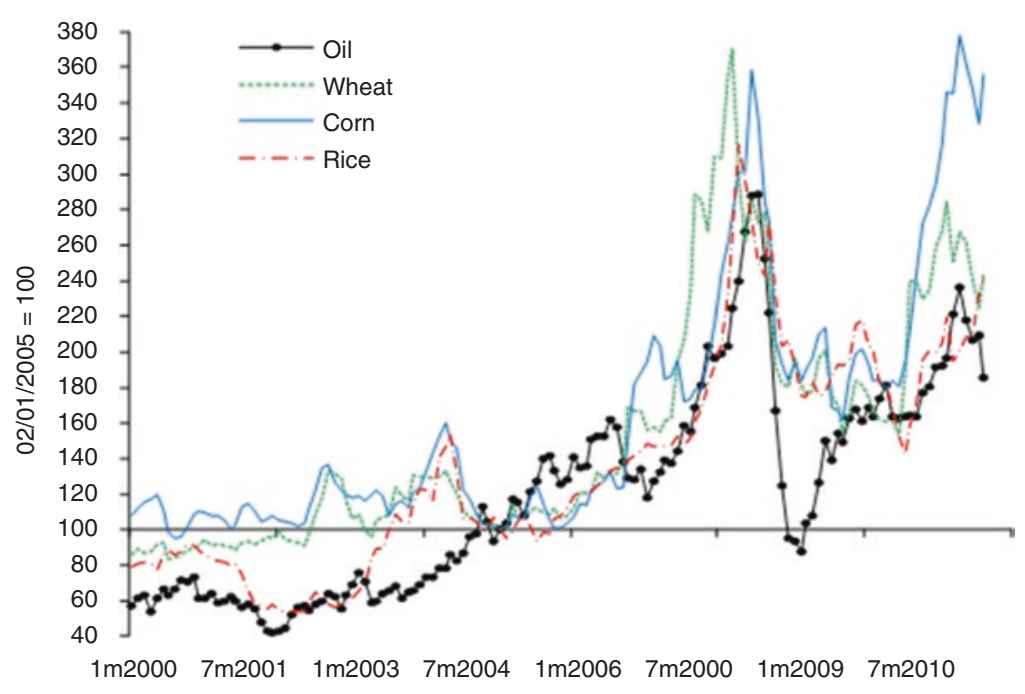

Fig. 2.5 Bull and bear markets of commodities futures prices. (Source: NYMEX, CBOT)

relaxing the financial crises of emerging market economies (Fig. 2.4). Sequences of bull and bear markets shape commodity price dynamics in general, particularly over the past 15 years when financial "investors" become increasingly active in commodity derivative trading. The parallel price movements of crude oil, wheat, corn and rice before and after 2008 indicate the importance of "bulls" and "bears" in blowing up asset values before the crisis and melting them down during the crisis (Fig. 2.5).

Under the condition of widely fluctuating exchange rates and commodity prices, and of a positive interest-growth differential (Fig. 2.1), financial and non-financial business shifted activities from the real to financial investment and short-term speculation ("finance capitalism"). This shift was fostered by financial innovations, in particular derivatives of all kinds which became the most important vehicles for speculation (Fig. 2.11). The change in incentive conditions for making profits had two effects. First, the sequence of bull and bear markets of exchange rates, commodity prices, interest rates, stock prices and house prices triggered "oil price shocks" and debt crises of developing countries and caused the great financial crisis of 2008. Second, non-financial business reduced the accumulation of real capital and, hence, the creation of "normal" jobs.

Europe was much more affected by this shift in capital accumulation from real to financial assets. First, the sustainability of the European Social Model depends much more on a high level of employment (consisting of "normal" jobs) as compared to the US model ("working-poor jobs" did - and still do - not fit to the European welfare state system). Second, economic policy in the USA emancipated itself from the concept of a rules-based fiscal and monetary policy in the late 1980s and has since then followed a (primitive) Keynesian policy. As a consequence, real capital accumulation picked up in the USA in the 1990s, whereas it declined in many European countries, in particular in Germany (Fig. 2.12). 
Between the early 1970s and the late 1980s, unemployment rose strongly in (Western) Europe (in spite of the decline in the wage share (Fig. 2.1)). As unemployment is extremely costly for welfare states (due to rising social expenditures and falling receipts from taxes and social security contributions), also the public debt increased with some time lag. This rise was further strengthened by the persistently positive interest-growth differential (Fig. 2.1).

Over the 1990s and 2000s (until the financial crisis), the "twin problems" unemployment and public debt could be mitigated (Fig. 2.16), however, at the expense of damaging the European Social Model: the decline in the rate of unemployment was primarily the (statistical) result of the expansion of atypical jobs due to labour market deregulations since economic growth remained weak (fluctuating around an annual rate of $2 \%$ (Fig. 2.1)). The (small) reduction in the ratio of public debt to GDP was achieved mainly through cutting social expenditures, i.e. through weakening the welfare state. At the same time, stock prices boomed like never before (Figs. 2.8 and 2.11).

After the burst of the "internet bubble" in 2000/2002, three simultaneous bull markets developed (house prices, stock prices and commodity prices) which tilted around 2007 into three bear markets: house prices started to decline in late 2006, followed by stock prices and finally by commodity prices (Fig. 2.6). Insofar as bull markets and bear markets are the most typical feature of asset price dynamics, the financial crisis can be considered as result of "business as usual". However, a simultaneous devaluation of house wealth, stock wealth and commodity wealth seldom occurs; the last time this happened was in 1929.

The mutually reinforcing effects of simultaneous bear markets become evident if one compares the period 2007/2008 to that of 2000/2002 (Fig. 2.5). In the latter case, the strong devaluation of stock wealth was to a great extent compensated by the revaluation of real estate wealth (a recession followed nevertheless). The devaluation of stock wealth, housing wealth and commodity wealth contracted balance sheets, reducing the equity of all asset holders. As the share of equity in total assets was lowest in the case of banks (in order to profit from leverage), they would have collapsed had the government not refinanced them - at costs of several trillion dollars. The measures for bailing out the banks and for stimulating the economy in the Great Recession of 2009 caused budget deficits to soar to unsustainable levels, in particular in those countries like Greece where the deficit had been (much) too high already before the crisis. When the newly elected (socialist) Greek government admitted that the previous (conservative) government had reported wrong budget data to the European Commission and asked for financial support, all other EMU governments refused to grant it.

The intention of rejecting support was to "punish" Greece for the misbehaviour of its government; the effect, however, was an epidemic rise in interest rates not only in Greece but also in Ireland, Portugal, Spain and Italy. The rejection signalled financial market agents that Greece and other EMU states could in fact slide into bankruptcy since the respective national central bank cannot provide the government with credits in a monetary union. As a consequence (investment), banks and hedge funds started to speculate on the bankruptcy of EMU member states through 


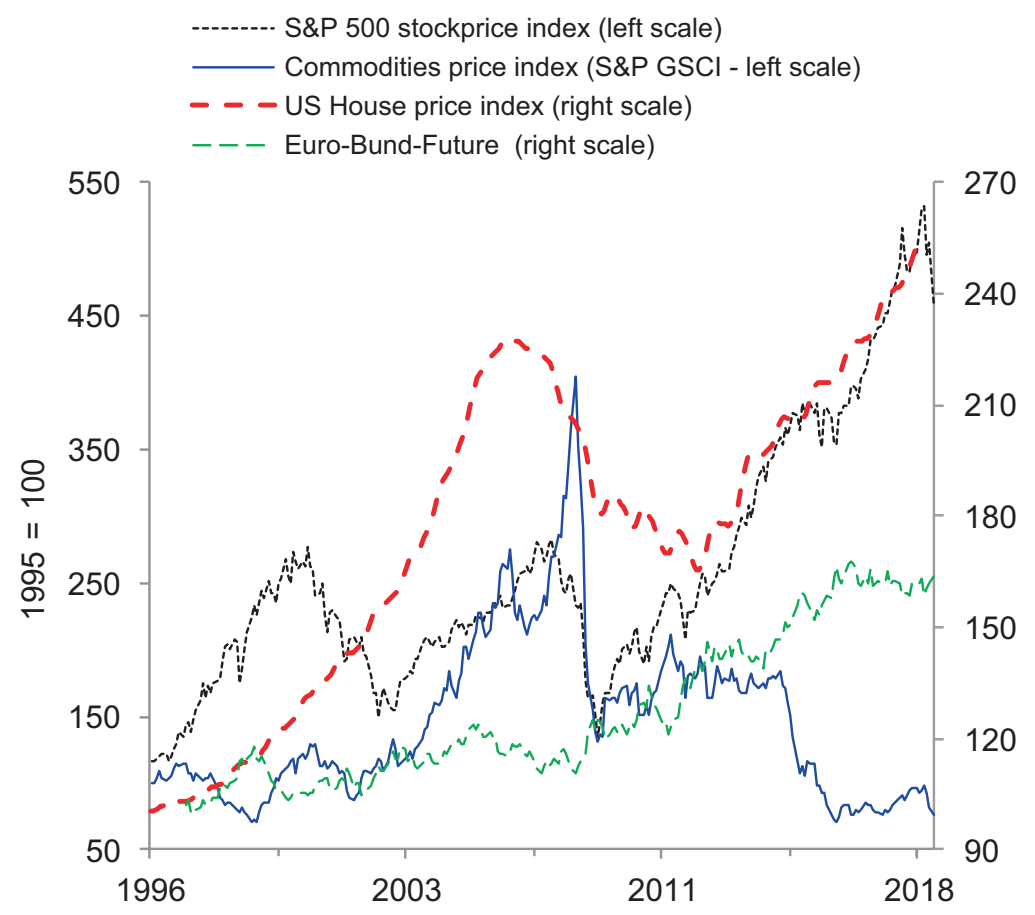

Fig. 2.6 Valuation of stock, commodity, real estate and bond wealth. (Source: Yahoo Finance, Case-Shiller, Standard \& Poors, Onvista)

"credit default swaps" (CDS), first against Greece, then against Ireland, Portugal, Spain and Italy. This business turned out to be extremely profitable for the "early birds": CDS premia with respect to government bonds of Greece or Portugal rose by a factor of 10. Hence, also the value of those CDS contracts, which were concluded at an earlier stage, rose by the same factor. Interest rates on government bonds of the "targeted" states increased in tandem with the CDS premia.

At the same time, investors seeking a "save haven" drove up prices of government bonds of Germany and other "good" countries: As a consequence, interest rates declined in the "North" where the economy started to recover and soared in the "South" where the crisis deepened. The "interest split" of the euro area caused also political tensions to rise. When the interest rate "epidemic" reached Spain and Italy (causing CDS premia and the contract values to rise by a factor of 5), ECB president Mario Draghi underlined in July 2012 the determination of the ECB "to do whatever it takes to preserve the euro". This announcement together with an extremely expansionary monetary policy stopped the "game" of speculating on the bankruptcy of EMU member states. Interest rates began to fall in all EMU countries (had the ECB president Trichet adopted such a policy already 2 years earlier, the euro crisis would have been prevented). 
In March 2015, the ECB intensified its loose monetary policy though "quantitative easing", i.e. asset purchases from banks to the amount of $60 \mathrm{bn}$. $€$ per month (this sum was increased to $80 \mathrm{bn}$. $€$ in March 2016). This policy was indispensable for saving the euro since the government of countries as big as Spain or Italy could not be (re)financed through the euro bail-out fund (European Financial Stability Facility, later European Stability Mechanism).

The developments leading into the euro crisis can be summarized as follows: the refusal of EU policy makers to give financial support to Greece in fall 2009 triggered a bear market in government bonds of Greece, Ireland, Portugal, Spain and Italy and a bull market in government bonds of Germany and the other "good" countries. The move of the ECB towards an extreme loose monetary policy in 2012 turned the bear market in government bonds of Southern European countries into a bull market and strengthened also the stock bull market which had already taken off in March 2009 - not only in Europe but on a global scale. At the same time, also house prices boomed again, this time not only in the USA and the UK but also in continental Europe. Once again, three bull markets of stock prices, house prices and bond prices have built up the potential for three bear markets (Fig. 2.6; "Euro Bund Future" indicates the development of German 10-year government bond prices).

\section{Macroeconomic Effects of Bull Markets and Bear Markets}

The long swings of asset prices impact upon the real economy through their valuation effects. Rising stock prices, for example, increase the financial wealth of their owners (also indirectly via pension and college funds, etc.). If they trust in the permanent character of the (re)valuation, gains, they will increase their expenditure as US households did during the 1990s. The expansionary effects of bull market feedback on the strength of the asset appreciation, in particular, if the latter does not increase other people's liabilities at the same time (e.g. if the bull market concerns stocks or residential buildings). By the same token, bear markets dampen the real economy. For example, a fall in the value of savings for pensions or college costs will cause households to save more (consume less) out of their current income.

In the case of exchange rates, one has also to take into account the effects of appreciation and depreciation trends on capital flows, on terms of trade and the related trade flows as well as on the re(de)valuation of international debts. These effects are strongest in the case of "bulls" and "bears" of the dollar exchange rate since commodities are priced in dollars, and most international debts, in particular of emerging countries, are held in dollars. As a consequence, any dollar appreciation (trend) improves "ceteris paribus" the terms of trade of net commodity exporters (at the expense of net importers) and appreciates dollar debts/assets.

The opposite holds in the case of a dollar depreciation (trend). The net effect of the related redistribution processes on the global economy is mostly negative as the demand of winners rises more slowly than the demand of losers falls. This is particularly true in the case of strong oil price changes. When they rise as in the 1970s (in reaction to the preceding dollar depreciations), the additional demand of 
oil-exporting countries falls short of the decline in the demand of industrial countries. However, when oil prices fall strongly (as 1984/1986 or 2014/2016), the net demand effect is again negative.

The strongest influence on the real economy exerts house price fluctuations: during a bull market, house owners feel richer, increase consumption and/or take up additional credits using the rising house value as collateral. In addition, real estate developers or private speculators buy and/or build houses as speculation vehicle. These activities are fettered by financial innovations which enable creditors to bundle claims against house owners in "asset-backed security" (ABS) and sell them as "collateralized debt obligation" (CDO). When the bull market tilts into a bear market, the values of houses often sink below the value of the respective credits, and the owners (have to) leave their home. As a consequence, also the ABSs and CDOs become (almost) worthless. This wealth meltdown wipes out equity and forces the losers to radically cut expenditures. By the end of the bear market, asset management firms like BlackRock or Blackstone buy houses at low prices and rent them out, partly to their former owners. When a new bull market takes off, these investors profit from the revaluation of houses (instead of their inhabitants).

In more general terms, during the upswing and downswing of asset prices, a redistribution process takes place. Who gets on the trend in its early stage makes profits at the expense of the "late-coming bandwagonists". As a group, the winners are the professional traders, and the losers are the amateurs (including many pension funds). A thought experiment clarifies the issue: If the level of stock prices at the end of the "bear" would be the same as at the beginning of the "bull", the overall value of stock wealth would be the same. However, its distribution has changed: The wealth of professionals (in the aggregate) has grown by the same amount by which the wealth of amateurs (in the aggregate) has shrunk. In accounting terms, the effects of asset price fluctuations are as follows. Any appreciation extends balance sheets, blowing up the equity of (net) asset holders and wiping out equity of (net) liability holders (e.g. of dollar debtors in the case of a dollar appreciation). The opposite holds for a depreciation process (Koo 2009). These effects of "bulls" and "bears" have become more pronounced since the 1990s due to the growing dominance of IFRS accounting standards (assets and liabilities have to be valued at their current market values).

The different channels through which the long swings of asset prices impact upon the real economy are rather neglected in macroeconomic theory. This is particularly true for the mainstream of the past decades since "New Classical Macroeconomics" and "New Keynesian Economics" exclude the possibility of "bulls" and "bears" by construction. ${ }^{4}$ John M. Keynes had stressed the role of uncertainty, emotions and social interaction like herding as fundamental reasons for the specific instability of financial markets (particularly in Chap. 12 of his "General

\footnotetext{
${ }^{4}$ Equilibrium theory can take into account "bubbles" which, however, are essentially different from bull markets: A bubble represents a non-fundamental, exploding equilibrium price path (equilibrium in the sense that expectations of rising prices are fulfilled), whereas a bull market is limited by the repercussions of the overvaluation on the real economy. Agents take these feedback effects into account. Hence, they know from the very beginning that any bull market comes to an end. In addition, equilibrium theory cannot explain the persistence of bear markets.
} 
Theory"), yet he did neither provide a theoretical elaboration of his insights nor integrate them into his general theory. ${ }^{5}$

Those two phenomena which have shaped economic development over the past decades and which represent characteristic features of finance capitalism have still to be theoretically explained: the tremendous rise in speed and volume of (derivatives) trading of stocks, bonds, foreign exchange and commodities, on the one hand, and the increase in the amplitude of long-term trends of these prices, on the other hand.

\section{How Bull and Bear Markets Are Brought About}

Asset prices fluctuate almost always around "underlying" trends. ${ }^{6}$ The phenomenon of "trending" repeats itself across different time scales ("self-similarity"). For example, there occur trends based on tick or minute data (Fig. 2.10) as well as trends based on daily data (Figs. 2.7, 2.8, and 2.9). "Technical" or "algorithmic" trading aims at exploiting the trending of asset prices. In the case of trend-following

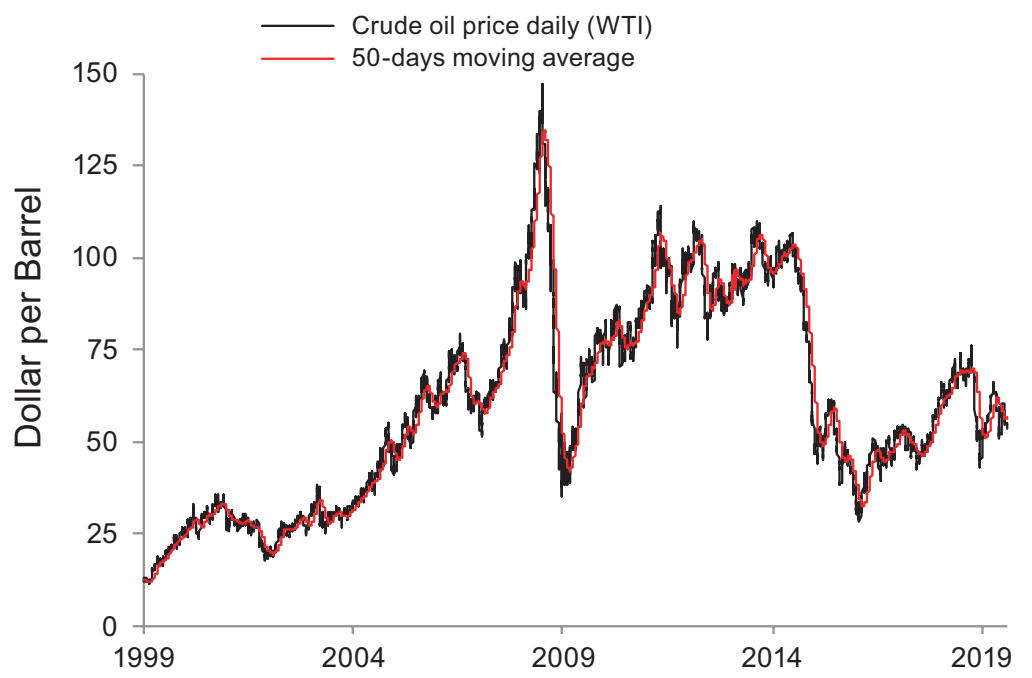

Fig. 2.7 Trending and speculation in the crude oil futures market. (Source: NYMEX)

\footnotetext{
${ }^{5}$ In a nutshell, these insights provided the microeconomic foundation of Keynes' macroeconomic theory ("homo humanus"). However, most "Keynesians" did not take Keynes' insights about the importance of uncertainty, emotions and social interactions serious. The main exception are "PostKeynesians", in particular Hyman P. Minsky. However, also Minsky dealt mainly with booms in credit markets and not with everyday business in financial markets of all types, namely, self-referential "money making" through speculation (see Schulmeister 2018, Chap. 5).

${ }^{6}$ Empirical research on asset price dynamics is documented in Schulmeister (2008, 2018, Chap. 9).
} 


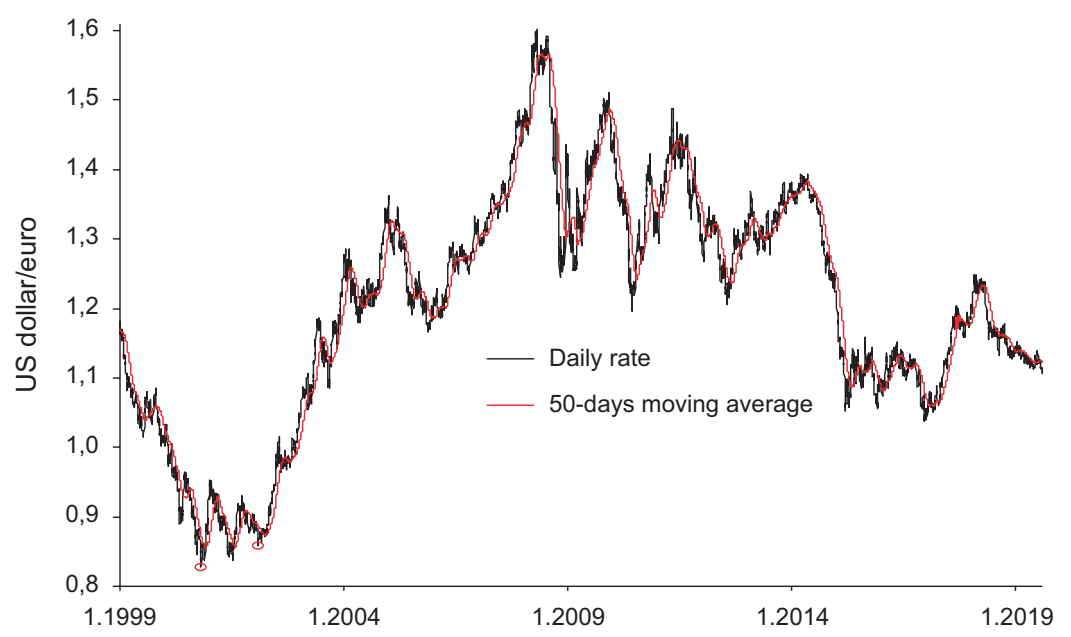

Fig. 2.8 Trending and speculation in the foreign exchange market. Daily US dollar/euro exchange rate

moving average models, a trader would open a long position (buy) when the current price crosses the MA (moving average) line from below and sells when the opposite occurs (Figs. 2.7 and 2.10). By contrast, contrarian models try to profit from trend reversals and, hence, change open positions when a trend "loses momentum". Technical models are applied to price data of almost any frequency (Figs. 2.7, 2.8, 2.9 , and 2.10). Due to the increasing use of intraday data, "algo trading" has become the most important driver of financial transactions. They rose from 15.5 times of world GDP to 72.4 times in 2007, declined in the aftermath of the financial crisis but then picked up again, at least in Europe (Fig. 2.11).

There operates an interaction between trending of asset prices and technical trading. On the one hand, traders use different models to exploit price runs, and, on the other hand, the aggregate behaviour of all models strengthens and lengthens the price runs. Long-term price trends result from the following process. "Mini-trends" (e.g. based on minute data) add up to one trend based on 10-minute data. Several of these trends accumulate to one trend based on hourly data and so on. Over an extended period of time (often several years), upwards (downwards) trends last longer than counter-movements, causing the price to rise (fall) in a stepwise process. As a consequence, all important asset prices like exchange rates, stock and bond prices as well as commodity prices fluctuate in irregular cycles ("long swings") around their fundamental equilibrium without any tendency to converge (Figs. 2.3, 2.5, 2.6, 2.7, 2.8, and 2.9). This evidence completely contradicts equilibrium theory according to which asset prices should - in reaction to news - jump to their new fundamental equilibrium. Hence, there should be neither short-term nor long-term trending.

The pattern of asset prices can be explained as result of the following trading behaviour. Price runs are usually triggered by news. In order to reduce the complexity of trading decisions under extreme time pressure, traders form only qualitative 


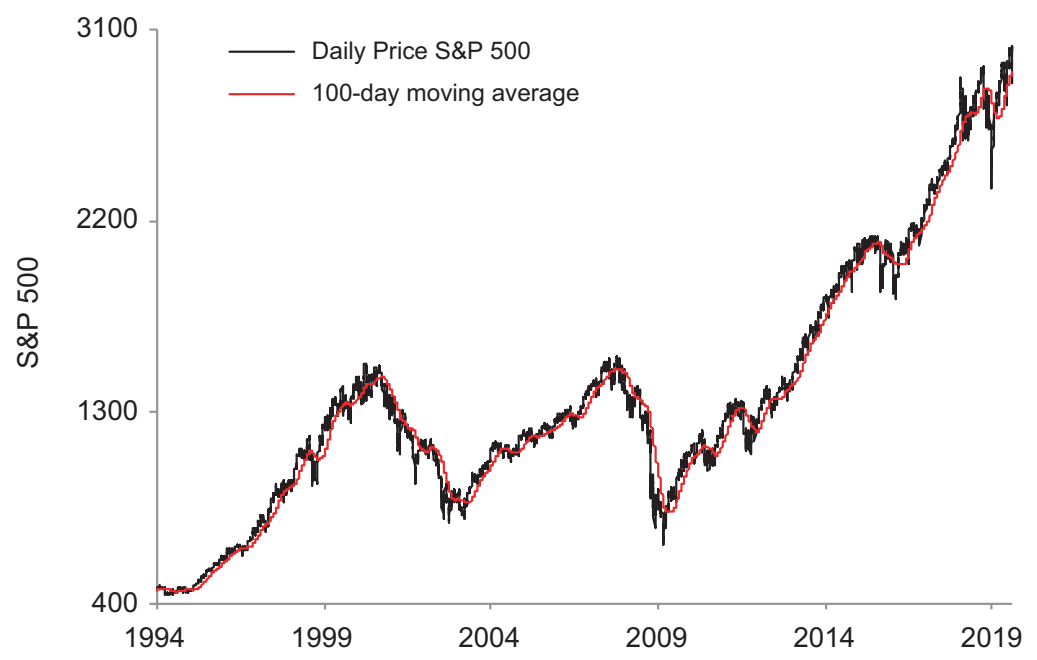

Fig. 2.9 Trending and speculation in the US stock market

a

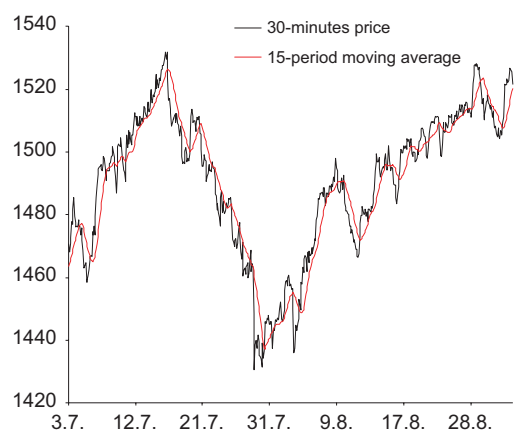

b

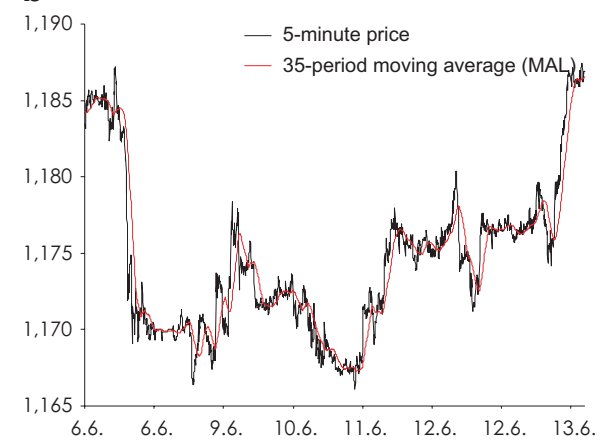

Fig. 2.10 Intraday asset price dynamics. (a) S\&P 500 stock index futures, July and August 2000. (b) Exchange rate dollar/euro, June 6 to June 13, 2003

expectations in reaction to news, i.e. expectations about the direction of the imminent price move. Subsequent to an initial upwards (downwards) price movement triggered by news, follows a cascade of buy (sell) signals stemming from trendfollowing technical trading systems. At first, the most price-sensitive models based on high frequency data ("fast models") produce signals, at last the slowest models based on hourly or daily data. When an upwards (downwards) trend loses momentum, contrarian models start to open short (long) positions, thereby contributing to a trend reversal. Most of the time there prevails an "expectational bias" in the market, in favour of or against an asset. Such a bias reflects the - optimistic/bullish or pessimistic/bearish - market sentiment. News in line with the prevailing bias get 

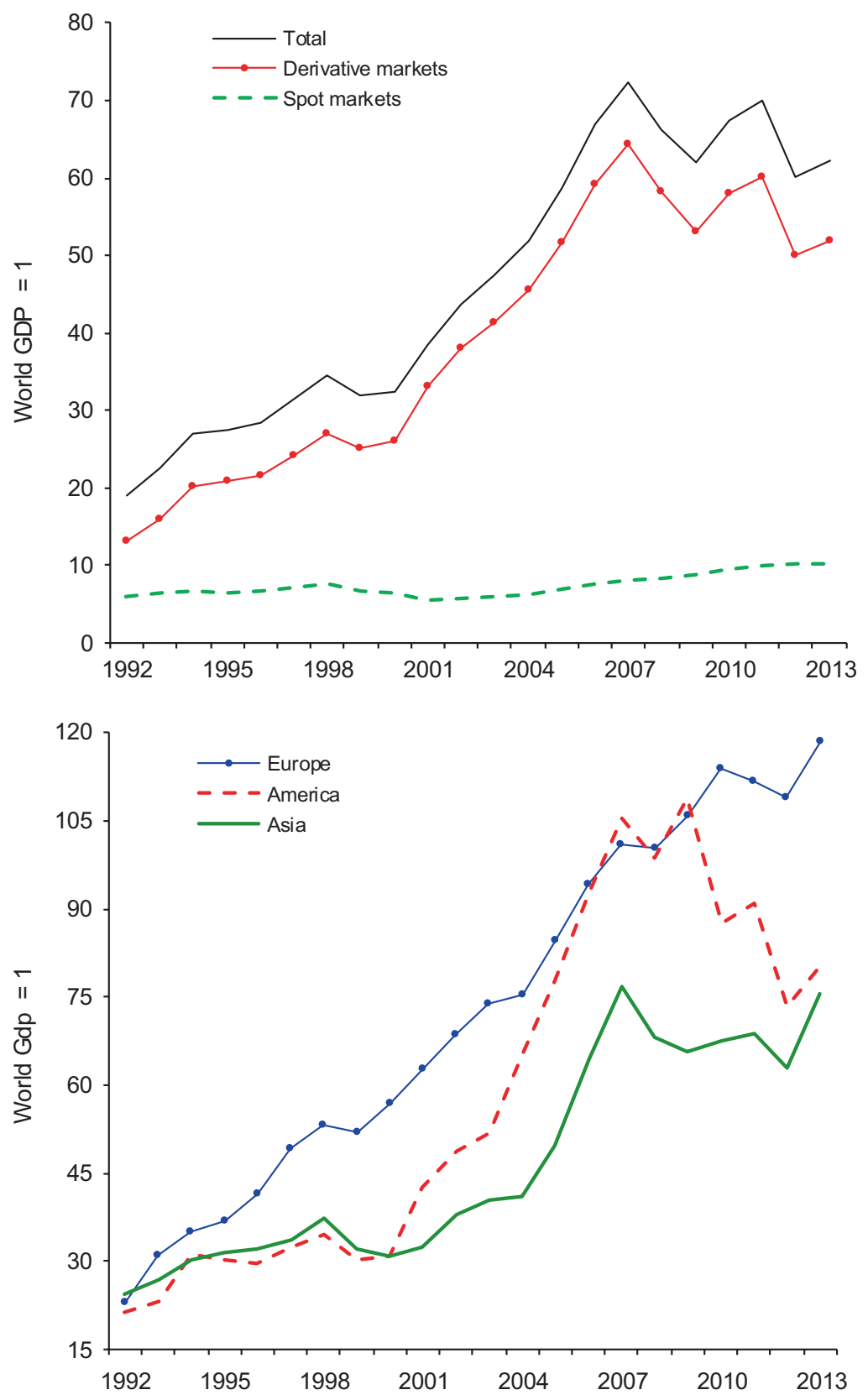

Fig. 2.11 Financial transactions in the world economy. (Source: WIFO) 
higher recognition and reaction than news which contradict the market mood. This behaviour causes price runs in line with the "market mood" to last longer than counter-movements, bringing about "bulls" and "bears".

The more the asset becomes over(under)valued, the greater becomes the probability of a change in the direction of the long-term trend: first, because market participants know from experience that any bull/bear market comes to an end; second, because there operate long-term "contrarians" in the market who sell (buy) in an "overbought" ("oversold") market; and third, because the effects of an over(under) valuation on the real economy progressively strengthen corrective forces (e.g. the deterioration of the current account and the related decline in economic growth in the case of a persistently overvalued currency).

To conclude, "overshooting" is not an exception due to some "shock" but the most characteristic property of long-term asset price dynamics. Exchange rates, stock prices and commodity prices fluctuate in a sequence of "bulls" and "bears" around their fundamental equilibrium without any tendency of convergence towards this level.

\section{A General Framework: Real Capitalism and Finance Capitalism ${ }^{7}$}

Over the past decades, economic policy guided by the neoliberal "navigation map" has dampened economic growth through two transmission channels. First, it led into recessions as results of the "oil price shocks" in 1993 and 1979 (triggered indirectly by giving up the fixed exchange rate system) and into the big financial crises in 1982 and 2008 (caused by boom-bust cycle of asset prices). Second, the intrinsic instability of exchange rates, commodity prices, interest rates and stock prices has shifted striving for profits from the real to the financial economy. Unemployment, precarious jobs, the public debt and rising inequality are just symptoms of a dysfunctional economic system, i.e. finance capitalism. Under real-capitalist conditions (until the 1970s), non-financial business focused on the accumulation of real assets: at stable exchange rates, commodity prices and - in Europe - stagnating stock prices as well as interest rates below growth rates, financial speculation did not make sense. Since the 1970s, however, the value of financial capital rose much faster than that of real capital (at current asset prices, hence, influenced not only by real/financial investment but also by the swings of asset prices (Fig. 2.12)).

In the following, I shall sketch a theoretical framework for the distinction between a real-capitalistic and a finance-capitalistic system. There exist three types of participation in the production process, labour, real capital and finance capital, and, hence, three types of economic and political interests (Table 2.1). The economic interests of real and finance capital stay in direct conflict with one another.

\footnotetext{
${ }^{7}$ The two types of a capitalist system are discussed more in detail in Schulmeister (2018, Chap. 8). A first sketch in English is in Schulmeister (2014) (this section draws on this article).
} 


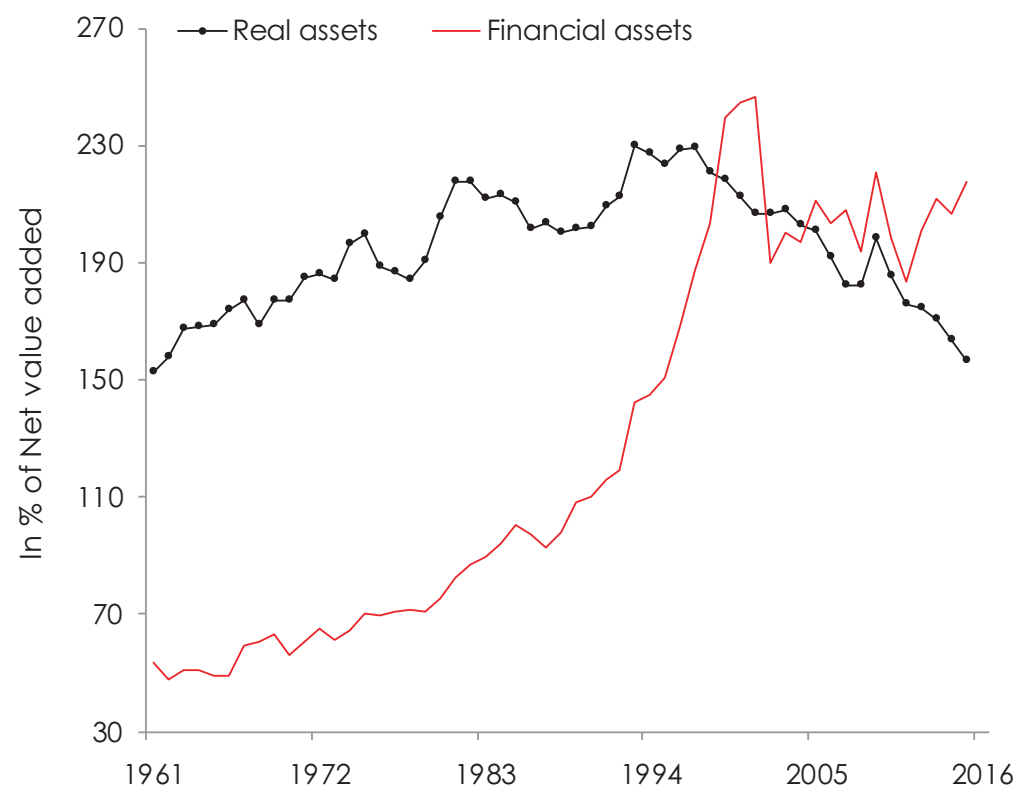

Fig. 2.12 Real and financial accumulation of non-financial business in Germany. (Source: Bundesbank, Destatis, WIFO)

Table 2.1 Labour, real capital, finance capital

\begin{tabular}{|c|c|c|c|}
\hline & Labour & Real capital & Finance capital \\
\hline Economic interests & $\begin{array}{l}\text { Full employment } \\
\text { Real wage increases }\end{array}$ & $\begin{array}{l}\text { High profitability of real } \\
\text { investments: } \\
\text { - Low interest rates } \\
\text { - Low exchange rates } \\
\text { - Stable financial markets }\end{array}$ & $\begin{array}{l}\text { High profitability of financial } \\
\text { investments: } \\
\text { - High interest rates } \\
\text { - High exchange rates } \\
\text { - Unstable financial markets }\end{array}$ \\
\hline Conflicts of interests & Rising wages & 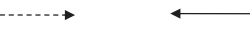 & $\rightarrow \quad$ Rising interest rates \\
\hline Potential coalition partners & Real capital & Labour or finance capital & Real capital \\
\hline $\begin{array}{l}\text { Economic interest in } \\
\text { state/government }\end{array}$ & $\begin{array}{l}\text { Full employment policy } \\
\text { Social security } \\
\text { Education } \\
\text { Public services }\end{array}$ & $\begin{array}{l}\text { Anticyclical policy } \\
\text { Growth policy: } \\
\text { Infrastructure } \\
\text { Education, etc. }\end{array}$ & $\begin{array}{l}\text { Strong central bank } \\
\text { Restrictive monetary policy } \\
\text { Privatisation of social security }\end{array}$ \\
\hline Political interests & $\begin{array}{l}\text { Strong welfare state } \\
\text { Strong trade unions }\end{array}$ & $\begin{array}{l}\text { Weak welfare state } \\
\text { Weak trade unions }\end{array}$ & $\begin{array}{l}\text { No welfare state } \\
\text { No trade unions }\end{array}$ \\
\hline
\end{tabular}

Real investments call for low interest rates and exchange rates, and stable financial markets, whereas financial investments and speculation profit from exactly the opposite conditions. The conflict of the ("purely") economic interests between real capital and labour can be considered less pronounced than the conflict between real 
capital and finance capital. For example, an increase in production costs due to higher wages leads to a much higher increase in final demand and, hence, in receipts of the business sector as compared to an equivalent cost increase caused by higher interest rates. Even though the interests of real capital and labour are different as regards the distribution of income, both factors have a common interest in generating a high overall income and, hence, in a strong and stable production growth.

The interests of labour, real capital and finance capital differ markedly also with respect to the role of government. Whereas labour profits from a comprehensive welfare state, real capital is mainly interested in government activities which foster real production over the long run (e.g. through improving infrastructure and the education system) and which stabilize it over the short run (e.g. through anti-cyclical policy measures). Finance capital is mainly interested in a strong central bank, a restrictive monetary policy and the privatization of social security (Table 2.1).

Neoclassical theory cannot consider the conflicts of interest between real capital and finance capital because it assumes that there exist only utility-maximizing individuals equipped with rational expectations. However, also Keynes and his followers did not provide a general framework to analyse the interaction between entrepreneurial interests and (financial) rentier interests (even though Keynes often referred to "rentiers"). By contrast, classical economists, in particular Adam Smith and David Ricardo, did focus on the relationship between rentiers, capitalists and workers; however, their rentiers were the landlords, whereas the modern rentier is primarily owner of financial assets.

For the same reason, one cannot identify "classes" of "real capitalists" and "finance capitalists" in modern society: non-financial corporations as well as employees own financial assets and have therefore also finance capital interests. It depends on the framework/incentive conditions of the economic system whether striving for profit concentrates on investment and innovation in the real sphere or in the financial sphere of the economy. In the first case, real capitalism prevails, in the second case finance capitalism (Table 2.2). The different system conditions also affect the financial sector: In the first case, banks act as "servants" for the real economy (financing investment, production and trade); in the second case, more and more (shadow) banks engage in "finance alchemy". Real capitalism consists of many conditions which complement and reinforce each other like a (tacit) coalition between the interests of labour and real capital (against the interests of finance capital). As a consequence, industrial relations are shaped by close cooperation ("Rhine capitalism"). Market and government, competition and cooperation are regarded as complementary; there prevail many - partly conflicting - targets of economic policy, reaching from stable growth to providing social security and a "fair" income distribution.

During real-capitalist periods (as between 1890 and 1914 and between $~ 1950$ and the mid-1970s or in China since the early 1980s), those economic theories dominate or are at least influential which underline the crisis-prone nature of capitalism (like Keynesian theories). These theories legitimize a strong government, an active economic policy and market regulations. Stable exchange rates as well as stable and low interest rates limit the returns from financial investment and speculation and focus striving for profits on the real economy (Figs. 2.1 and 2.2). Thus, real 
Table 2.2 Real capitalism and finance capitalism

\begin{tabular}{|c|c|c|}
\hline & Real capitalism & Finance capitalism \\
\hline Implicit coalition & Labour \& real capital & Real capital \& finance capital \\
\hline Business/unions & Corporatism & Conflict \\
\hline State/market & Complementary & Antagonistic \\
\hline $\begin{array}{l}\text { Targets of } \\
\text { economic policy }\end{array}$ & $\begin{array}{l}\text { Full employment, high growth, } \\
\text { social security. "Fair" } \\
\text { distribution of income and } \\
\text { wealth }\end{array}$ & $\begin{array}{l}\text { Price stability, "sound" public finances, } \\
\text { regulations of policy, de-regulation of } \\
\text { markets, declining government share. } \\
\text { International competitiveness }\end{array}$ \\
\hline $\begin{array}{l}\text { "Power center" of } \\
\text { economic policy }\end{array}$ & Government & Central bank \\
\hline Economic paradigm & Keynesianism & Monetarism/neoliberalism \\
\hline Diagnosis/therapy & Systemic & Symptom-oriented \\
\hline $\begin{array}{l}\text { Financial } \\
\text { conditions }\end{array}$ & $\begin{array}{l}\text { Interest rate }<\text { growth rate, } \\
\text { "calm" stock markets, stable } \\
\text { exchange rates and } \\
\text { commodities prices }\end{array}$ & $\begin{array}{l}\text { Interest rate }>\text { growth rate, boom and } \\
\text { bust on stock markets, unstable } \\
\text { exchange rates and commodities prices }\end{array}$ \\
\hline $\begin{array}{l}\text { Striving for profits } \\
\text { focuses on }\end{array}$ & $\begin{array}{l}\text { Real economy (positive-sum } \\
\text { game) }\end{array}$ & Finance economy (zero-sum game) \\
\hline Advantaged & Debitors & Creditors \\
\hline Economic model & $\begin{array}{l}\text { Social and regulated market } \\
\text { economy }\end{array}$ & "Pure" market economy \\
\hline $\begin{array}{l}\text { Focus of } \\
\text { globalization }\end{array}$ & $\begin{array}{l}\text { Stable monetary system, } \\
\text { regulation of financial markets, } \\
\text { deregulation of goods markets } \\
\text { (GATT), cooperative growth } \\
\text { strategies (Marshall plan, } \\
\text { development aid) }\end{array}$ & $\begin{array}{l}\text { De-globalization of politics through } \\
\text { rising competition of national } \\
\text { economies, deregulation of financial } \\
\text { markets, lack of global strategies to } \\
\text { tackle global problems (e. g., climate } \\
\text { change) }\end{array}$ \\
\hline
\end{tabular}

capitalism can be conceived as a positive-sum game. The theoretical/ideological basis of finance capitalism is (neo)liberal theories which call for a free market economy, especially for liberalizing financial markets, for a strong state as regards its core functions (security for citizens and their property) and for a weak state as regards welfare and labour regulations. These theories legitimate a (tacit) coalition between the interests of real and finance capital against the interests of labour because persistent full employment during a real-capitalist period shifts power in society from business to trade unions and from conservative to social-democratic parties. Therefore, entrepreneurs become (again) attracted by the (neo)liberal program. In this sense, the "excessive" success of real capitalism like full employment and the welfare state lays the ground for its fall (e.g. rising tensions in the relations between real capital and labour undermine their coalition).

Under a finance-capitalist regime, the volatility of exchange rates and commodities prices and the high level of interest rates have two effects on non-financial 
business. First, these conditions dampen its activities in the real sphere of the economy since they become more uncertain and more expensive. Second, these conditions make financial speculation and accumulation more attractive. This attraction is further increased by the emergence of financial innovations like derivatives which contribute to a dramatic expansion of financial markets shifting also the best human resources from real economy to "finance alchemy". At the same time, financial business becomes the dominant sector in the overall economy. The weak growth of real investment and, hence, of the overall economy causes unemployment and the public debt to rise which in turn strengthens the game "let your money work". For example, the shift in provisions for retirement from the welfare state system of "pay-asyou-go" to the (finance-capitalist) system of individual investment in financial assets lengthens stock market booms. Thus, the discrepancy between the market value of financial assets and their underlying in the real economy widens. This development leads to "corrections" in the form of financial crises (the crisis of 2008 can be seen as a particularly big correction as it concerned three bull markets at the same time). Whereas trading in asset markets represents just a zero-sum game, finance capitalism as a whole becomes a negative-sum game in its final stage: the destabilization of the most important prices for entrepreneurial activities like exchange rates, stock prices and interest rates together with the effects of financial crises progressively dampen the real economy. The system starts to implode through a series of crises, deepened by austerity policy. In this sense, the accumulation of negative outcomes of finance capitalism lays the ground for its own fall.

\section{Employment Under Real-Capitalist and Finance-Capitalist Conditions}

According to the mainstream (neoclassical) economic theory, supply and demand in the labour market determine the level of real wages and employment. When unemployment rises as a consequence of" demand shocks" such as financial crises or oil price shocks, job losses can be compensated only by real wage moderation. Higher wage flexibility is, however, hampered by unemployment benefits, labour protection, minimum wages and the power of unions (characteristic components of the European Social Model). As a matter of fact, however, labour costs are a function of real wages relative to labour productivity. In Europe, the latter has been growing even faster than wages since the late 1970s (and much faster than in the USA), exactly during that period when unemployment was rising (the wage share in national income declined noticeably (Fig. 2.1)). In addition, if the "rigidity" of European labour markets were truly important, this would have to show up in a less efficient allocation of labour and thus weaker growth of productivity as compared to the USA. Actually, however, labour productivity has been growing faster in Europe than in the USA - in tandem with the capital-labour ratio (capital intensity). 

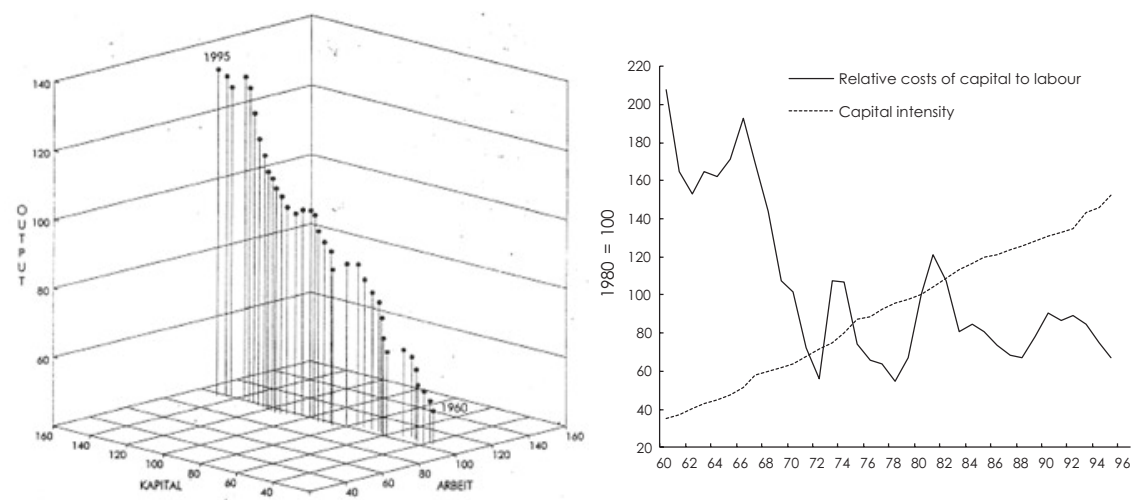

Fig. 2.13 Input, output and relative factor prices in the overall economy: Germany. (Source: OECD, WIFO)

The neoliberal explanation of labour demand rests on the (neoclassical) production function where capital input and labour input can be substituted for each other as a function of relative factor prices. However, an analysis of the observed realizations in the K-L-Y space in the USA, Germany and Japan (overall economy and 12 subsectors) between 1960 and 1995 reveals the following stylized facts:

- Capital intensity grows year after year, i.e. monotonically; the shift to ever more capital-intensive technologies is driven by technical progress and, hence, irreversible.

- The capital-labour ratio is unrelated to shifts in the factor price ratio (Fig. 2.13).

- Labour productivity grows in tandem with capital intensity: The higher and better the capital equipment of a worker becomes, the higher gets his productivity.

A linear-limitational production function with an irreversibly rising slope of the production rays fits these observations better than the neoclassical production function: in the short term, the factor input ratio is fixed; if the output is to be increased, labour and capital inputs need to be raised proportionally, and short-term demand for labour will be mostly influenced by expectations concerning demand in the goods markets; in the long term, capital intensity increases as a function of technical progress rather than of factor prices - more capital per labour is associated with a different quality of capital, meaning that labour productivity rises with capital intensity. An increase in output can be realized by either of two ways (or a mixture of both):

1. Movement along a ray with constant capital-labour ratios: capital intensity and labour productivity remain constant; the additional output is achieved by a greater input of capital and labour of the same quality.

2. Movement to a steeper production ray: the additional output is achieved by the increase and, hence, improvement of capital per labour unit and by the related learning process on the part of workers, capital intensity and labour productivity rise. 


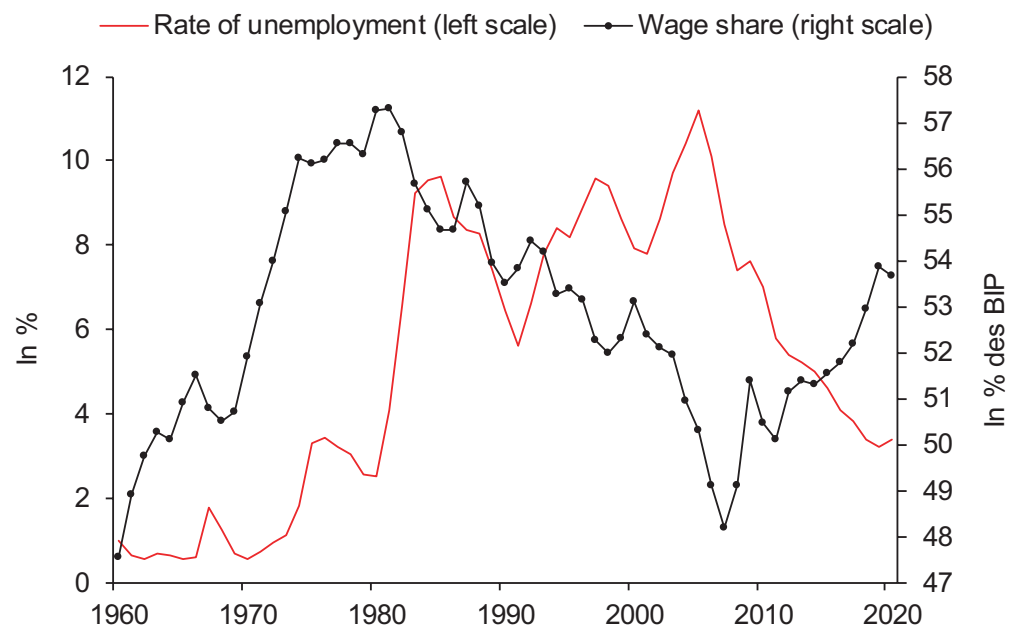

Fig. 2.14 Wage share and the rate of unemployment in Germany. (Source: Eurostat, OECD)

Under these conditions, the dynamics of job creation depends on the dynamics of real capital accumulation and of technical progress. The latter is to a large extent the result of (basic) innovations stemming from the "world of engineers" (interacting with the economic system). The dynamics of real capital accumulation depends primarily on the (expected) profitability of activities in the goods markets as compared to those in the financial markets. These observations and considerations suggest that the essence of persistent unemployment is sketched by analogy to the musical chair game: There are 100 chairs, 110 people want to get one, and those persons who do not get a chair are the least qualified. If they are (re)qualified, they might get a chair in the next rounds, yet, at the expense of others.

From this perspective, high and persistent unemployment is due to a shortage of jobs. To overcome the problem, job creation must become less risky and more profitable for entrepreneurs. This calls for real-capitalist framework conditions, not for lower wages (high/full employment in the 1960s was associated with wages rising faster than labour productivity - the opposite has been the case afterwards (Fig. 2.14)).

\section{Public Finances Under Real-Capitalist and Finance-Capitalist Conditions}

The ratio of public debt to GDP was declining in (Western) Europe for 20 years from $70 \%$ to $40 \%$ when the welfare state was built up, and it has been rising to roughly $100 \%$ since the 1970 s in spite of consolidation efforts (Fig. 2.16). This development casts doubt on the belief that the government has direct control over its fiscal stance. Instead of a symptom-oriented "diagnosis", one has to take into account how the different sectors of the economy - households, business, 
government and the rest of the world (ROW) - behave under real-capitalist and finance-capitalist framework conditions. ${ }^{8}$ If, e.g. the business sector reduces its deficit in a recession, then the government suffers from a rising deficit due to the operation of the automatic stabilizers (and eventually also due to discretionary measures). If the business sector increases its deficit again for financing real investments, then the government can easily improve on its balance during the recovery. The recession in Germany in 1967 and the subsequent years is a good example for the interaction of the financial balances under real-capitalist conditions (Fig. 2.15).

Over the medium and long run, real-capitalist incentive conditions ensure that the business sector takes over household saving in the form of investment credits and transforms it into real capital and jobs (Fig. 2.15). As a consequence, the government's budget remains in balance, and the debt-to-GDP ratio declines since the rate of interest lies below the rate of economic growth (Fig. 2.16). Under these conditions, the surpluses and financial assets of private households (roughly) equal the deficits and financial liabilities of the business sector.

Finance-capitalist conditions change the interaction of financial balances and the dynamics of debts/assets in three respects. First, recessions occur more frequently than in a real-capitalist regime due to turbulences like oil price "shocks", interest rate "shocks" and dollar exchange rate "shocks". Second, recoveries become progressively weaker as financial instability and the related profit opportunities from speculation dampen real investments. Third, the rate of interest is higher than the rate of economic growth.

The dynamics of public debt is driven by two factors, the accumulation of (primary) deficits and the interest-growth differential. The latter does impact upon of the development of the public debt mainly indirectly, i.e. through the adjustment of the business sector to a positive or negative interest-growth differential. ${ }^{9}$ The reason for that is clear-cut: if the rate of interest exceeds the rate of growth (in nominal terms), any debtor (sector) has to run a primary surplus in order to stabilize its debt relative to GDP ("dynamic budget constraint"). To achieve such a surplus, nonfinancial business reduces real investment in favour of financial accumulation (Figs. 2.12 and 2.15). At the same time, also financial businesses and households run primary surpluses (e.g. private households - a creditor sector - save usually more than their net interest income). Under this condition, the government can achieve a primary surplus only if the rest of the world runs/accepts a primary current account deficit (the primary balances of all sectors sum up to zero). Germany, for example, was able to stabilize its fiscal stance mainly through rising surpluses visà-vis (and at the expense of) other countries.

\footnotetext{
${ }^{8}$ In the following, we specify only non-financial business since the financial balance of the financial sector was close to zero most of the time.

${ }^{9}$ When calculating the interest-growth differential, the distinction between nominal and real terms does not matter as both the interest rate and the growth rate have to be deflated with the same index of the general price level, i.e. the GDP deflator. However, in the context of analysing the interaction of financial balances of sectors, one should operate generally with nominal figures (balances cannot be deflated).
} 


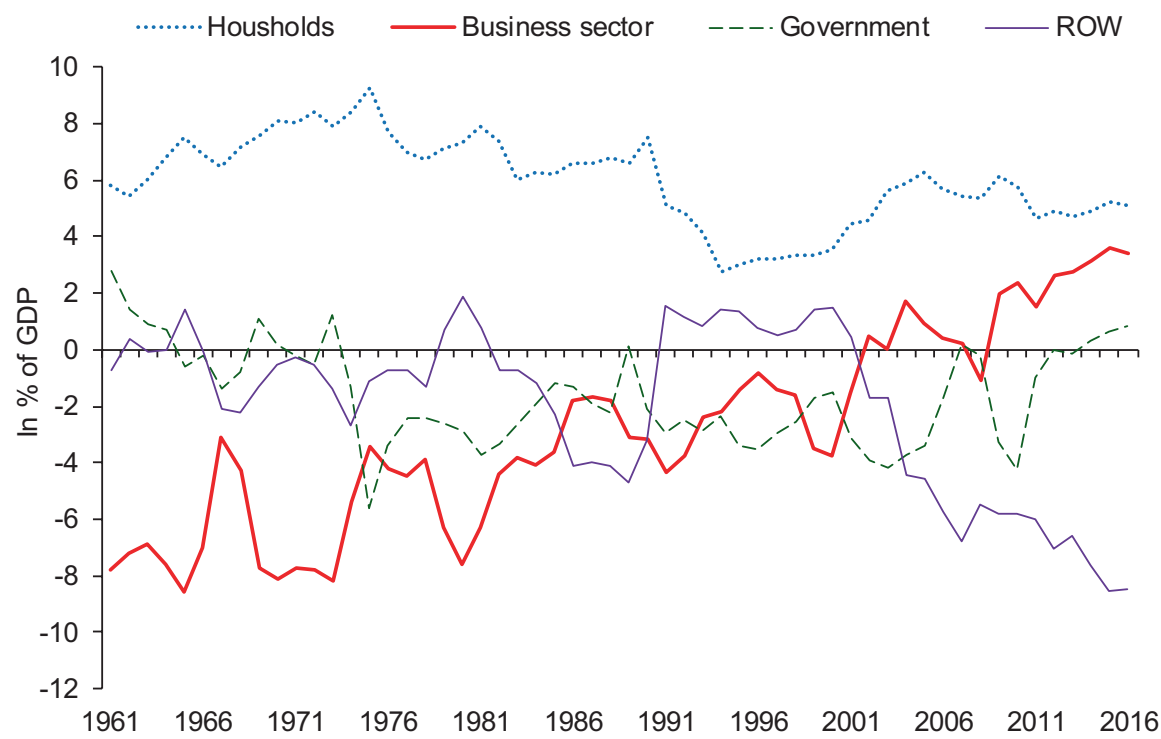

Fig. 2.15 Financial balances in Germany. (Source: Deutsche Bundesbank)

To summarize, finance-capitalist conditions in general and a positive interestgrowth differential in particular inevitably lead to a rise in public indebtedness and in global imbalances (if countries compensate the decline in the deficit of nonfinancial business through rising current account surpluses). This conclusion is in line with the empirical evidence. Under the incentive conditions of the 1950s and 1970s, the surpluses of households were taken over by the business sector in the form of deficits (Fig. 2.15) in order to finance the accumulation of real capital and, hence, the creation of jobs (Fig. 2.13). Economic growth at full employment enabled governments to build up the welfare state and keep the budget in balance at the same time. At a negative interest-growth differential, public debt declined relative to GDP (Fig. 2.16).

Since the 1970s, the finance-capitalist framework conditions induced non-financial business to reduce its deficit und to become a surplus sector in almost all industrial countries (like Germany (Fig. 2.15)): real investments were reduced in favour of financial investments, the stock of real assets has been declining relative to financial assets (Fig. 2.12), job creation and economic growth slowed down, and unemployment rose so that most countries have been running budget deficits (even Germany (Fig. 2.15)). ${ }^{10}$ Given the positive interest-growth differential, the public

\footnotetext{
${ }^{10}$ Only in recent years did Germany achieve a balanced or even a surplus budget, however, at the expense of the rest of the world: The European Monetary Union enabled Germany to fully profit from its restrictive wage and fiscal policy since the appreciations vis-à-vis Germany's euro partner countries were no longer possible. The German contribution to the development of the "euro crisis" is documented in detail in Schulmeister (2018, Chaps. 11, 12, and 13).
} 

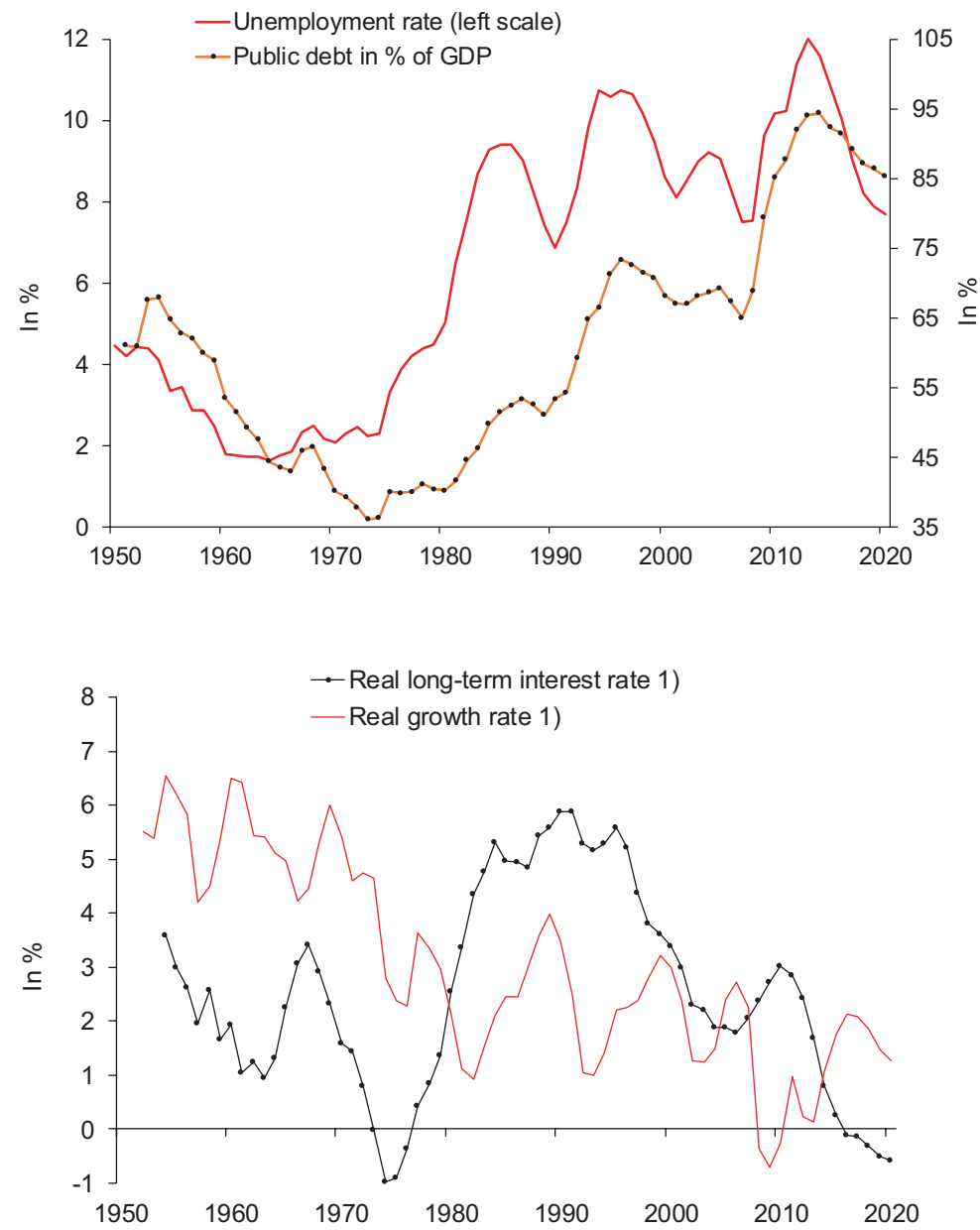

Fig. 2.16 Unemployment, public debt and the interest-growth differential in Western Europe. ${ }^{13-}$ years moving average. (Source: OECD, Eurostat, WIFO)

debt-to-GDP ratio has risen strongly over the long run (Fig. 2.16). The fiscal compact (signed in 2012) represents a further step in a series of attempts of EU politics to govern the fiscal stance of a country through certain rules (the first attempt consisted in the 3\%-deficit rule in the Treaty of Maastricht of 1992). In addition to the $3 \%$ rule as maximum of the general budget deficit, there is a second rule for the structural budget deficit which must not exceed $0.5 \%$ of GDP. This holds for all states with a debt-to-GDP ratio exceeding $60 \%$. According to the debt brake rule, these states have also to reduce this ratio by at least one twentieth (5\%) per year of the exceeded percentage points (e.g. if a state has a debt of $100 \%$ of GDP, it should reduce this ratio by $2 \%$ points each year). 
The most problematic rule concerns the structural deficit since the latter is a theoretical construction and cannot be directly calculated. Hence, the room for manoeuvre of fiscal policy can be restricted by the estimation method of structural deficits. This holds true in particular for the method used by the European Commission. These objections shall be concretized, taking the development in Spain after the crisis of 2008 as example (Fig. 2.17; all data stem from EC data bases, Fall 2013).

The financial crisis and the collapse of the real estate bubble caused a deep recession in 2009; unemployment and the budget deficit increased sharply. As unemployment did not decline afterwards, it became "natural" - by theoretical and methodological construction, the NAWRU follows the actual unemployment rate (Fig. 2.17). Since less employable people are fed into a Cobb-Douglas function, potential output started to decline. As a consequence, the output gap did not rise in spite of the deepening of the crisis but stays at roughly $4 \%$. Therefore, most of the actual deficit became "structural" (the EC estimates the cyclical component in general as roughly $50 \%$ of the output gap). The excessive structural deficit forced the government to more austerity. In 2011, transfers stagnated (in spite of unemployment rising above 20\%), and government consumption shrunk. These measures induced a further decline of GDP in 2012 (together with tax increases which however did not result in higher receipts due to the new recession). As a consequence,
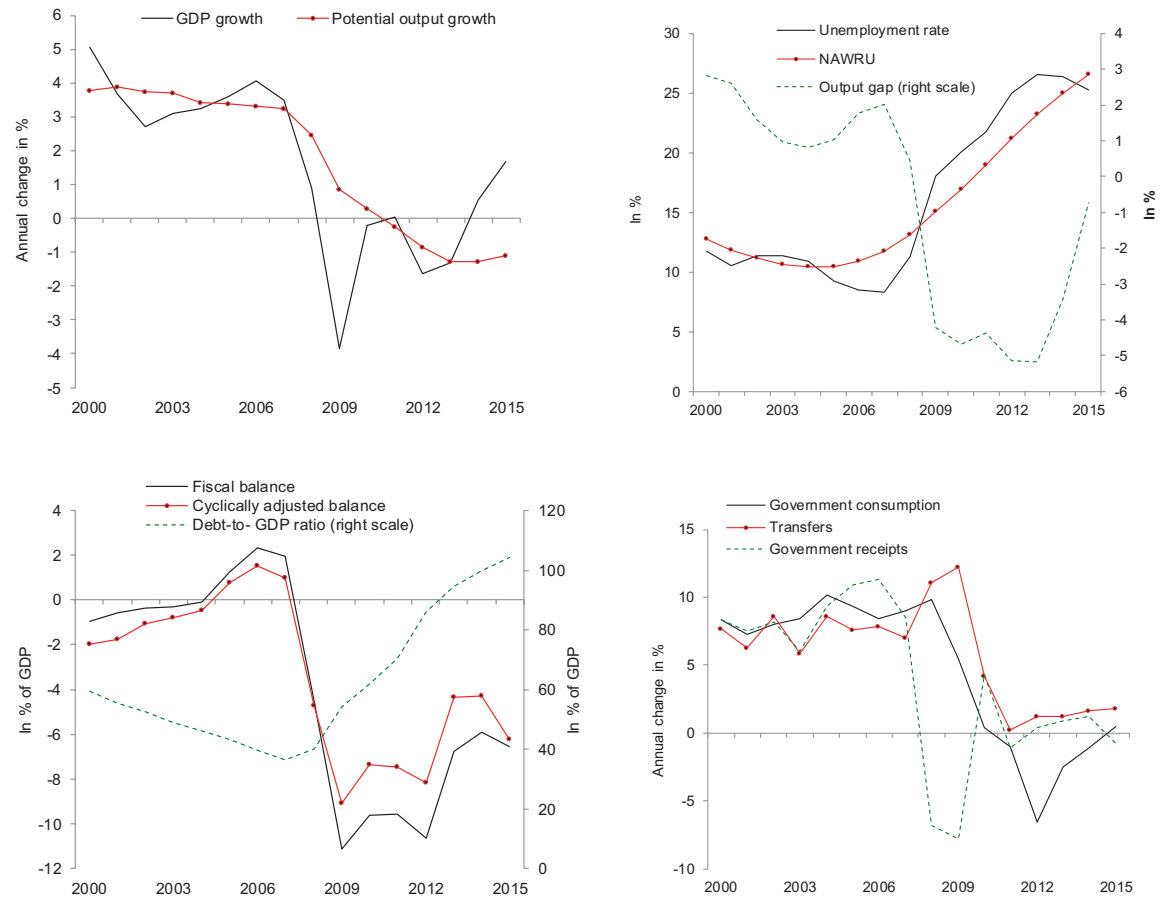

Fig. 2.17 Output, unemployment and the fiscal stance of Spain. (Source: Eurostat) 
the fiscal stance improved much less than expected, calling for further austerity. In the meantime, the debt-to-GDP ratio was rising from $40 \%$ to more than $80 \%$. If economic policy had continued to follow the fiscal rules, a downwards spiral would have developed. Fortunately, policy in Spain but also in Portugal and France deliberately (though tacitly) ignored the fiscal compact from 2013 onwards and took some expansionary measures. The structural balance of these states by far exceeded the $0.5 \%$ benchmark (whereas Italy tried to stick to this rule), yet no excessive deficit procedure was initiated by the European Commission. Together with the extremely loose monetary policy of the ECB, the moderate expansionary fiscal policy enabled the economy of these countries to recover.

\section{Production of Economic Theories and Long-Term Economic Development}

The observations presented so far cast doubts on the most fundamental propositions of neoclassical theory which has become once again the paradigm in economics (completed by "rational expectations"). Hence, this theory provided the basis of the "navigation map" of economic policy in the EU. But how could a theory remain dominant whose most fundamental propositions cannot be reconciled with the empirical evidence, in particular as regards the price dynamics in those markets which come closest to the theoretically ideal market, i.e. the financial markets? This section addresses this puzzle by reconsidering the interaction between economic developments and theory production.

The abatement of the revolution of 1848 was followed by a period of strong growth of the real economy (railways, construction), ideologically based on "laissez-faire liberalism". Marx and Engels explained the rising inequality and the misery of the working class as necessary outcome of capitalism which must be overcome on the basis of socialist theories. Together with their (real) wealth grew the temptation of "industrial capitalists" to (also) become "money capitalists" (Marx), e.g. to get even richer through speculation in the stock market, but also in real estate. By the late 1860s, stock and house prices started to rise more and more. The financecapitalist boom ended abruptly with the crash of 1873: Both bull markets tilted into bear markets leading into the "long depression."

On the academic level, "laissez-faire theories" came under attack; instead, concepts became popular which stressed the role of economic actors as social beings and which called for an active state, be it through building up a social state ("Kathedersozialisten" like Gustav Schmoller), be it through (protectionist) industrial policy (e.g. Friedrich List). In addition, also the more radical socialist/Marxist theories influenced the economists' debates. The longer the depression lasted, the more oppressing became the social problems, and the bigger became the power of 
the workers' movement (in 1875, the "Sozialistische deutsche Arbeiterpartei" was founded in Gotha, unifying two socialist forerunner parties). As a reaction, the basic components of the welfare state (health and pension insurance) were introduced in Germany by chancellor Bismarck and afterwards in most other European countries.

The improved confidence in the state, new investment opportunities through implementing new technologies (electricity and chemistry), stable financial conditions through fixed exchange rates (gold standard) and low interest rates and the related wave of globalisation contributed to the real-capitalist expansion of the "belle époque" ( 1890 to 1914). This was particularly true for Germany where all kinds of futures contracts were banned by law in 1896 (after a wave of wheat speculation had collapsed). Germany became the leading country in industrial production, and the capital of the UK became the leading financial centre.

On the academic level, neoclassical theory became the paradigm in economics. It had been developed since the 1870s (independently) by William Jevons, Carl Menger and Leon Walras and is strictly based on the interaction of individual agents in markets. In ideological terms, the concept of the "homo oeconomicus" and, hence, of individualism can be considered a reaction to the rising influence of socialist theories.

After World War I, the dominance of the "free-market view" facilitated the development of one of the strongest stock bull markets in history: Over only 4 years between 1925 and 1929 - stock prices almost quadrupled in the USA, people took up more and more credits to finance buying stocks and to "let their money work". The boom then spilled over to other industrial countries. The crash of 1929 caused a recession so that budget deficits widened. Economic policy followed the advice of mainstream economists to adopt an austerity policy according to neoclassical theory. This policy paved the way into the Great Depression, together with the collapse of the gold standard, competitive devaluations and other forms of protectionism.

The consequences of the depression were so catastrophic that also the learning process enforced by this crisis was deep. It resulted in a new macroeconomic theory (provided by Keynes), in an active economic policy focusing on full employment, in stable exchange rates, deregulation of goods markets but strict regulation of financial markets. Two other developments promoted prosperity. First, confidence was strengthened through building up the welfare state. Second, there prevailed a tight coherence between the technological paradigm (Fordism) and the economic paradigm (Keynesian welfare model).

The success of the European Social Model laid the ground for its own decline: Full employment and building up the welfare state shifted power from business to unions which asked for (more) employee participation and for a redistribution in favour of wages (Fig. 2.14). The "Zeitgeist" shifted to the left (1968, etc.) and brought social-democratic parties to power as in Germany and Austria. The environmental movement took off and attacked the capitalist model as obsolescent (the "Club of Rome" was founded 1970). All these developments caused "big business" to support the neoliberal movement against full employment, Keynesianism and the 
welfare state. ${ }^{11}$ The stepwise realization of the monetarists' demand for deregulation of financial markets transformed the system from a real-capitalist into a financecapitalist regime.

All important steps on the long way from prosperity into the present crisis - from moving to "flexible" exchange rates in 1971 to the financial crisis of 2008 and the subsequent euro crisis - were guided by the recommendations of neoliberal theories. ${ }^{12}$ Yet, this "Weltanschauung" still dominates at the academic level, in international organizations, in governmental institutions (ministries), in the media and in politics. The main reason for the persistence of neoliberalism lies in its history: never before had the enforcement of an economic paradigm so systematically been prepared, realized and anchored in the minds of the elites. This process began already during the Great Depression.

In 1931, Hayek became professor at the London School of Economics (LSE) at the age of 32 and turned soon into the most famous opponent of Keynes in the debates over the role of economic policy in the Great Depression. After the overwhelming success of Keynes' "General Theory" (1936), Hayek became an outsider within the economists' profession and began to focus on planning a movement against the foreseeable advance of the welfare state, legitimized by Keynes' theory. Hayek participated in a first meeting of like-minded economists and sociologists in Paris in August 1938 (during this "Colloque Lippmann", the term "neo-liberalism" was coined). During the war, Hayek provided the ideological fundament for the neoliberal movement with his "Road to Serfdom" (1944). As next step, Hayek founded the Mont Pelerin Society (MPS) in 1947. This network links together top scientific economists ("original thinkers" in Hayek's words - as yet, eight MPS members got the "Nobel prize"), other intellectuals working in academia, media or think tanks ("second-hand dealers in ideas"), politicians (like Ludwig Erhard) and wealthy people as financiers of MPS activities.

Hayek took the "Fabian Society" as model for the neoliberal movement. This leftist group of social reformers had successfully changed values and attitudes in the British society between the 1880s and the 1920s. In "The Intellectuals and Socialism" (1949), Hayek proposed to his combatants that also the neoliberal movement should focus on influencing the intellectuals because "once the most active part of the intellectuals has been converted to a set of beliefs, the process by which

\footnotetext{
${ }^{11}$ As early as 1943 did Michal Kalecki foresee the long-term political consequences of full employment policy: "Lasting full employment is not at all to their ['business leaders'] liking". The workers would "get out of hand" and the "captains of industry" would be anxious to "teach them a lesson" (...). In this situation a powerful alliance is likely to be formed between big business and rentier interests, and they would probably find more than one economist to declare that the situation was manifestly unsound" (Kalecki 1990, p. 355).

${ }^{12}$ One has to distinguish between (at least) three neoliberal schools, the Austrian school (Hayek and Co.), the Chicago (neoclassical/monetarist/New Classical) school (Friedman, Lucas and Co.) and the German ordoliberal school (one could also add the Virginia school with Buchanan as leading figure which, however, is a close "ally" of the Chicago school). These schools differ fundamentally in their assumptions and methods; however, they arrive at practically the same policy recommendations (see Schulmeister, Chap. 6).
} 
these become generally accepted is almost automatic and irresistible" (quoted in Jones 2012, p. 80). Hayek was convinced that "the building of a free society" through defeating Keynesianism and weakening the welfare state could actually be achieved even though this might take "two or three generations". ${ }^{13}$ As first step, one needed anti-Keynesian theories, produced by the "original thinkers", which would then be "translated" in the language of ordinary people by the "second-hand dealers in ideas" and promoted by think tanks.

In the 1950s and 1960s, Hayek, Friedman, Stigler, Becker, Coase and Buchanan (to name only the most prominent MPS members and - later - "Nobel laureates") produced a great variety of theories, directed against the then dominant economic paradigm, i.e. Keynesianism:

- Financial speculation is predominantly rational and, hence, stabilizing (Friedman 1953). This (tautological) "proof" legitimated later the deregulation of financial markets.

- Keynesian fiscal policy has little effect since households base their consumption on their "permanent" and not on their current income (Friedman 1957).

- In his "opus magnum", Hayek called for the restriction of any activities of the state besides protecting the individual liberty and property of its citizens (Hayek 1960).

- George Stigler (University of Chicago) developed the concept of "regulatory capture" according to which market regulations are (ab)used by lobby groups (Stigler 1971).

- At the University of Virginia, James Buchanan and Gordon Tullock built up the "public-choice school": Politicians act mainly their private interest (Buchanan and Tullock 1962).

- Gary Becker generalized the "homo oeconomicus": All human relationships such as love, marriage, parenthood, etc. are guided by rational utility maximization (Becker 1976).

- Friedman "proved" (together with Anna Schwartz) that the Great Depression was not caused by the stock market crash of 1929 and the subsequent austerity policy but by the central bank, i.e. by the state (Friedman and Schwartz 1963).

The presidential address of Milton Friedman at the meeting of the American Economic Association in 1967 signalled the start of the decisive attack (Friedman 1968): full employment policy is not only useless but detrimental because there exists a natural rate of unemployment. Any attempt to push unemployment below its level results in higher inflation. The whole argument was tautological: If one assumes that output is determined in real terms through market equilibria (vertical Phillips curve), then any monetary impulse can only have inflationary effects. The construction of Friedman's model was, however, brilliant: He took the modified

\footnotetext{
${ }^{13}$ Milton Friedman was more optimistic. He stated in his article "Neo-Liberalism and Its Prospects": "The stage is set for the growth of a new current of opinion to replace the old, to provide the philosophy that will guide the legislators of the next generation even though it can hardly affect those of this one". Quoted in Jones (2012, p. 85).
} 
Phillips curve (Samuelson and Solow 1960) as point of departure, which - erroneously - implied that economic policy can choose between inflation and unemployment. Such a choice turns out to be non-sense if one takes interest rates into account: Any rise in inflation causes nominal interest rates to rise and interest payments on outstanding debts to rise even faster so that investments and employment will decline with some lag. ${ }^{14}$ For more than a decade, monetarism became the dominant macroeconomic paradigm based on the quantity theory of money. However, being neoclassical thinkers and, hence, believing in "money does not matter", monetarists overlooked a trivial, yet fundamentally important fact: money is not only used for transactions with goods and services (PQ $\times \mathrm{Q})$ but also with financial assets of all kinds $(\mathrm{PF} \times \mathrm{QF}): \mathrm{M} \times \mathrm{V}=\mathrm{PQ} \times \mathrm{Q}+\mathrm{PF} \times \mathrm{QF}$.

Since the volume of financial transactions is many times bigger (and more unstable) than the volume of transactions with goods and services (Fig. 2.11), a stable relationship between money supply and $\mathrm{PQ} \times \mathrm{Q}$ is a theoretical impossibility (Schulmeister 2018, p. 88f and p. 157f). The collapse of the Bretton Woods system and the following dollar depreciation induced the first "oil price shock" followed by the first global recession since the 1930s. The "original thinkers" then used the coincidence of rising unemployment and rising inflation as disprove of the Phillips curve and of Keynesian theory in general. The "battle over the Phillips curve" marked the decisive defeat of Keynesian economics. As substitute, the old general equilibrium theory was restored and complemented by "rational expectations" (Lucas 1972): It is assumed that agents form their expectation according to the "true model" which is the model of the rational expectations of economists themselves (a Freudian projection). As some kind of terminological twist, Lucas and Co. called their approach "New Classical Macroeconomics" instead of "old neoclassical microeconomics".

Once any kind of non-rationality, uncertainty, social interaction and emotions were removed from the economic theorist's world, one no longer needed to account for different economic agents. Hence, the "new classical macroeconomists" constructed "dynamic general equilibrium (DSGE) models" based on "representative agents", preferably eternally living. In this world, expansionary fiscal policy is useless ("Ricardian equivalence"; Barro 1974) as is any kind of macroeconomic policy ("Lucas critique"; Lucas 1976). Business cycles can only be caused by technological shocks ("real business cycles"; Kydland and Prescott 1982). Once the "original thinkers" had produced economic theories, the intellectuals ("second-hand dealers in ideas") should sell them to the public. To this end, more and more neoliberal think tanks were founded like the "Institute for Economic Affairs" in the UK, the "Liberty Fund", the "Heritage Foundation" or the "Cato Institute" in the USA (to mention only the biggest "tanks"). Their number grew particularly fast after the

\footnotetext{
${ }^{14}$ To illustrate this accelerator effect, if inflation rises by $2 \%$ points causing the nominal interest rate to increase from $4 \%$ to $6 \%$, then interest payments rise by $50 \%$ (for credits at flexible rates). Phillips himself had (plausibly) interpreted the inverse relationship between the change in wages and unemployment as reflecting just the (unidirectional) influence of the employment situation on the bargaining power of unions (Phillips 1958).
} 
breakthrough of the neoliberal offensive in the 1970s. Since 1981 neoliberal think tanks are linked together through the "Atlas Network", it comprises today almost 500 institutions all over the world. ${ }^{15}$

Over several decades, the increasing dominance of the neoliberal "Weltanschauung" changed politics, values and attitudes. Slowly, "the market" became the highest (economic) being which transforms the individual egoisms into the social optimum with an "invisible hand". Therefore, men have to subordinate to market forces, even the democratically legitimized politics (see the notion "marketconform democracy" used by Chancellor Merkel). That "the market" appears to be a subject to which men have to adjust is also expressed in everyday language ("the markets discipline Greece with higher interest rates" - in its plural form, "markets" almost always means "financial markets"). Through turning the subject-object relationship between men and market upside down, neoliberalism became the most powerful ideology of anti-enlightenment and of de-politicizing politics: men cannot and/or should not organize consciously development processes in society through political coordination (e.g. by building up a comprehensive welfare state). Instead, social development should be driven by market competition of individuals, coordinated by the "invisible hand". The propagation of this ideology - massively fostered by the breakdown of "real socialism" in 1989 and thereafter - strengthened the feeling of people to be exposed to incomprehensible economic fluctuations, in particular of globalized financial markets. At the same time, austerity policies weakened the trust in the welfare state. Right-wing populists address the feelings of uncertainty, fear of the future and anger and promise to "clean up" the system.

\section{The "Long Cycle" as Sequence of Real-Capitalist and Finance-Capitalist Regimes}

The Russian economist Nikolai Kondratieff was the first to discover the phenomenon of the "long cycle" or "long wave" in economic development. In his interpretation, the upswing is caused by technological innovations like the steam engine, railways or electricity; the downswing sets in when the technology has already been widely diffused (Kondratieff 1926).

However, the post-war long cycle can hardly be explained by this model since fundamental technological innovations like microelectronics in all its manifestations, biotechnology and nanotechnology were developed primarily since the 1970s, i.e. over the downswing phase (over the 1950s and 1960s, no fundamentally new technologies had been developed). Based on the distinction between real and finance

\footnotetext{
${ }^{15}$ See www.atlasnetwork.org. For details of how the neoliberal master minds organized the advancement and diffusion of their ideology, see Walpen (2004), Burgin (2012), and Jones (2012). The essence of this literature is summarized in Schulmeister, Chap. 6.
} 
capital, the long cycle might better be understood as a sequence of real-capitalist and finance-capitalist regimes.

The upwards phase of the long cycle is brought about through incentive conditions which focus profit-seeking on activities in the real economy (financial speculation is restricted). Real accumulation is booming; finance capital grows in tandem with real capital or somewhat slower due to the undervaluation of financial assets, in particular of stocks. The longer the boom lasts, the more real and financial wealth is accumulated. Their owners become increasingly interested in "let our money work" also through financial speculation. At the same time, the economic and political position of workers improve due to full/high employment. Trade unions and leftist parties go on the offensive. Liberal or neoliberal theories and political concepts become more attractive for rentiers as well entrepreneurs. In this way, the success of real capitalism, i.e. the accumulation of wealth and full employment, lays the ground for a change in the economic paradigm and in the respective "navigation map" for politics.

Under finance-capitalist incentive conditions, economic growth declines, unemployment and the public debt rise, austerity policies deepen the crisis. The "synchronization" of bull and bear markets causes asset revaluations, followed by devaluations which lead finally into a deep financial and economic crisis as in 1873, 1929 and 2008. In this way, the failure of finance capitalism lays the ground for its decline and the search for new framework conditions during the trough phase of the long cycle. The incentive structure is changed in favour of entrepreneurial activities, in particular through financial regulations and a more active economic as well as social policy. ${ }^{16}$ The key empirical facts concerning the long cycle over the last 150 years have already been sketched in sections "Framework Conditions and Economic Performance of Western Capitalism during the 1960s and 1970s" and "Public Finances Under Real-Capitalist and Finance-Capitalist Conditions". Here, they are only shortly recapitulated. After the boom of the real economy in the $1850 \mathrm{~s}$ and 1860 s, speculation led to the great real estate, bank and stock market crash of 1873 , followed by the "long depression". The tensions in society became more pronounced as did the power of the workers' movement. As a reaction, the basic components of the welfare state were introduced in the $1880 \mathrm{~s}$.

The related stabilization of purchasing power and, hence, of final demand, but also stable exchange rates, low interest rates and the first wave of globalisation,

\footnotetext{
${ }^{16}$ In a profound and original study in economic history, Arrighi (2010) combines a similar model of long waves with Fernand Braudel's concept of centre and periphery and the related role of the hegemon in the global economy. In Arrighi's interpretation, an economic and political system becomes the hegemon during a real-capitalist upwards phase and then moves to "high finance" and by doing so finances the upwards phase of its successor. In this way, the Republic of Genoa financed the expansion of the Dutch Republics during the sixteenth century which then financed the industrialization of Great Britain. When London moved to "high finance" in the second half of the nineteenth century, it financed the US expansion. When the Wall Street became dominant in the late 1970s, the USA started to finance the expansion of the Chinese economy through joint ventures which also provide a continuous technology transfer (it goes without saying that this note is only an extremely simplified sketch of Arrighi's concept of "systemic cycles of accumulation").
} 
contributed to the real-capitalist expansion of the "belle époque" ( 1980 to 1914). Over the "roaring 1920s", the mood of "let your money work" broadened and led to a spectacular stock-market boom which crashed in October 1929 together with real estate and commodity prices. The subsequent financial crisis and austerity policies - derived from neoclassical theory - paved the way into the Great Depression. The consequences of the depression were so catastrophic that also the learning process enforced by this crisis evolved in an in-depth manner. It resulted in a new macroeconomic theory (Keynesianism), an active economic policy focusing on stable growth and full employment, stable exchange rates ("Bretton Woods"), deregulation of goods markets (e.g. though the GATT rounds) but strict regulation of financial markets.

Whereas the Kondratieff model stresses the importance of technological innovations as driving force of the upswing, the model presented here stresses the importance of the relationship between technical and social innovations, i.e. of the coherence/incoherence between the technological paradigm and the socio-economic paradigm. The post-war prosperity phase is a good example: The "Fordistic" type of (mass) production fitted well to the Keynesian paradigm of the 1950s and 1960s which legitimates the strengthening and stabilizing of mass consumption. Expressed in more general terms: the (in)coherence between the technological paradigm and the economic and social paradigm is a key factor in the dynamics of the long cycle. When technological innovations take place, they usually cannot be fully utilized because there is a lack of accommodating social innovations. For example, Fordistic mass production was already adopted in the 1920s but could not be fully used within the "laissez-faire paradigm".

In an analogous way, one can argue that nowadays those social innovations are missing which would accommodate the technological innovations of the last decades in such a way that the society as a whole can profit from progress in technology as well as in the socio-economic relations. The contradiction between the progression in technology and regression in economics, i.e. the return to the old "laissez-faire paradigm", is one important feature of the current crisis (in natural sciences a return to an old paradigm is unconceivable).

\section{The European Model and the US Model Under Real- Capitalist and Finance-Capitalist Conditions}

Table 2.3 summarizes the main differences between the European Social Model and the US model of society in a stylized manner. These differences have developed over several centuries, whereas changes between real-capitalist and finance-capitalist framework conditions take place within few decades. The roots of the European Social Model lie in the traditionally great importance of citizens being embedded in social contexts. The respective organizations range from the feudal system or the guilds of craftsmen in medieval times to interest groups like trade unions and up to the modern welfare state. In the USA, by contrast, competition as individuals is the most important form of economic interaction - not the least because the USA has 
Table 2.3 European model versus US model

\begin{tabular}{|c|c|c|}
\hline & Europe & USA \\
\hline $\begin{array}{l}\text { Long-term development } \\
\text { path }\end{array}$ & $\begin{array}{l}\text { Citizens embedded in social contexts } \\
\text { (feudal system, communities, interest } \\
\text { groups, welfare state) }\end{array}$ & $\begin{array}{l}\text { Citizens as (former) } \\
\text { immigrants: Mentality of } \\
\text { adventurers, Competition } \\
\text { as dominant form of } \\
\text { social interaction }\end{array}$ \\
\hline Pursuit of interests & $\begin{array}{l}\text { Mainly through organisations (unions, } \\
\text { etc.) }\end{array}$ & $\begin{array}{l}\text { Predominantly as } \\
\text { individuals in markets }\end{array}$ \\
\hline Fundamental values & $\begin{array}{l}\text { Individual freedom and social justice } \\
\text { ("Liberte, egalite, fraternite") }\end{array}$ & $\begin{array}{l}\text { Individual freedom } \\
\text { ("pursuit of happiness") }\end{array}$ \\
\hline $\begin{array}{l}\text { Importance of trade unions } \\
\text { and organisations of } \\
\text { entrepreneurs }\end{array}$ & Great & Little \\
\hline Labour relations & Corporatism & $\begin{array}{l}\text { No institutionalized } \\
\text { cooperation }\end{array}$ \\
\hline Labour markets & Regulated & "Hire and fire" \\
\hline $\begin{array}{l}\text { Insurance against illness, } \\
\text { old-age poverty, } \\
\text { unemployment }\end{array}$ & Provided by welfare state & $\begin{array}{l}\text { Mainly private (or no) } \\
\text { insurance, unemployment } \\
\text { benefits modest }\end{array}$ \\
\hline Education system & Primarily run by welfare state & Mainly private \\
\hline Relationship market/state & Complementary & Antagonistic \\
\hline $\begin{array}{l}\text { Importance of the welfare } \\
\text { state }\end{array}$ & Great & Little \\
\hline $\begin{array}{l}\text { Importance of the financial } \\
\text { sector }\end{array}$ & (Traditionally) Less important & Very important \\
\hline Focus of making profits & (Traditionally) Real economy & $\begin{array}{l}\text { Real and financial } \\
\text { economy }\end{array}$ \\
\hline "Economic culture" & $\begin{array}{l}\text { "Real capitalism" combined with } \\
\text { welfare state }\end{array}$ & $\begin{array}{l}\text { "Real and financial } \\
\text { capitalism" ("Silicon } \\
\text { Valley culture" combined } \\
\text { with "Wall Street } \\
\text { culture") }\end{array}$ \\
\hline
\end{tabular}

evolved from a society of immigrants in which the fight for survival and expansion is of central importance. As a consequence, organisations like trade unions or political parties as a means of pursuit of interests play a comparatively greater role in Europe. Individual freedom, social justice and solidarity can be considered the key values of European society ("liberté, egalité, fraternité"). In the USA, by contrast, individual freedom ranges by far the highest ("pursuit of happiness").

These differences are also reflected by the way how insurance against basic risks of life is provided and how the education system is organized. In both respects, the welfare state plays a much more important role in Europe as compared to the USA. As a consequence, the relationship between market and state is (traditionally) considered complementary in Europe but rather antagonistic in the USA.

Significant differences have also been prevailing as regards the relationship between the real and the financial sphere of the economy and the related "economic culture". The economies in (continental) Europe have been focused on the real economy. In the USA (and also in the UK), the "Wall Street" (and the "City") plays 
Table 2.4 Europe and USA under real and finance capitalism

\begin{tabular}{l|l|l|l}
\hline \multirow{2}{*}{} & \multicolumn{2}{|l}{ Macro-economic framework conditions } \\
\cline { 2 - 4 } & & & $\begin{array}{l}\text { Mixed (Bastard- } \\
\text { Keynesian monetary } \\
\text { and fiscal policy, } \\
\text { speculation focused } \\
\text { on stock market) }\end{array}$ \\
\hline Eunditions & Real capitalism & Finance capitalism & - \\
\hline US-Model & $\begin{array}{l}\text { Europe until } \\
\sim 1973 / 1980\end{array}$ & $\begin{array}{l}\text { Europe since } \\
\sim 1973 / 1980\end{array}$ & - \\
\hline & US until $\sim 1973 / 1980$ & US since $~ 1973 / 1980$ & US since $\sim 1990$ \\
\hline
\end{tabular}

a key role in the economic system. Since the early 1990s, the practice of economic policy in the EU has been staying in an increasing contradiction to the principles of the European Social Model. This policy was shaped by the following general guidelines (Table 2.4): restrictive regulation of fiscal and monetary policy and deregulation of financial, goods and labour markets. These neoliberal guidelines have progressively weakened the European welfare state. At the same time, US economic policy has been following a "trivial Keynesian" course.

The fiscal rules were established in 1992 in the Treaty of Maastricht and have then been tightened through the Treaty of Amsterdam (1997) and 2012 through the Fiscal Compact. In the USA, by contrast, fiscal policy has been following a pronounced countercyclical course. For example, in and after recessions, the government increased the budget deficit deliberately and strongly. Afterwards it did not adopt a savings policy but let the automatic stabilizers care for a continuous improvement of the fiscal stance. ${ }^{17}$ Monetary policy in the euro area is shaped by the statute of ECB which gives price stability the highest priority and leaves almost no room for other economic targets. By contrast, the US central bank considers growth of production and employment as important as price stability. US authorities try to support the own economy not only by means of an active fiscal and monetary policy but also by stimulating exports through an undervalued dollar exchange rate. For example, during and after the recessions in 1991 and 2001, the "talking the dollar down" on behalf of US politicians contributed to strong depreciations of the US currency. After the Great Recession of 2009, this strategy failed due to the deepening of the euro crisis which caused the euro exchange rate to decline.

To summarize, a comparison of the fiscal and monetary policy adopted by the EU, on the one hand, and by the USA, on the other, suggests that an exchange of concepts took tacitly place around 1990. The EU took over the monetarist approach of regulating fiscal and monetary policy in a restrictive manner, whereas the USA adopted a "trivial Keynesian" approach. An evaluation of the realization of the four combinations of real/finance capitalism, on the one hand, and the European/US model, on the other hand, in post-war history (plus the special case of the US

\footnotetext{
${ }^{17}$ This "trivial Keynesian" course was and is facilitated by the privilege of issuing the main international reserve currency, the US dollar. Since the USA can finance its external deficit in its national currency, it is much less financially constraint than all other countries. This helps also to finance the US government deficit.
} 
strategy since the early 1990s) suggests that the best performance was realized in Europe over the 1950s and 1960s due to the coherence between the principles of the European Social Model and a real-capitalist incentive structure. The worst performance can be attributed to the (inconsistent) combination of finance-capitalist conditions and the European model, i.e. the development in the EU over the last 20 years.

\section{References}

Arrighi, G. (2010). The long twentieth century (2nd ed.). London: Verso.

Barro, R. (1974). Are government bonds net wealth? Journal of Political Economy, 82(6), $1095-1117$.

Becker, G. S. (1976). The economic approach to human behavior. Chicago: University of Chicago Press.

Buchanan, J., \& Tullock, G. (1962). The calculus of consent - Logical foundations of constitutional democracy. Ann Arbor: University of Michigan Press.

Burgin, A. (2012). The great persuasion: Reinventing free markets since the depression. Cambridge: Harvard University Press.

Friedman, M. (1953). The case for flexible exchange rates. In Essays in positive economics. Chicago: University of Chicago Press.

Friedman, M. (1957). A Theory of the Consumption Function, Princeton University Press.

Friedman, M. (1968). The role of monetary policy. American Economic Review, 58(1), 1.

Friedman, M., \& Schwartz, A. J. (1963). A monetary history of the United States 1867-1960. Princeton: Princeton University Press.

Hayek, F. A. (1960). The constitution of liberty. Chicago: University of Chicago Press.

Jones, D. S. (2012). Masters of the universe: Hayek, Friedman, and the birth of neoliberal politics. Princeton: Princeton University Press.

Kalecki, M. (1990). Political aspects of full employment. In Collected works of Michal Kalecki (Vol. I). Oxford: Clarendon Press.

Kondratieff, N. D. (1926). Die langen Wellen der Konjunktur, Archiv für Sozialwissenschaft und Sozialpolitik. Band, 56, 573-609.

Koo, R. (2009). The holy grail of macroeconomics: Lessons from Japans great recession. New York: Wiley.

Kydland, F. E., \& Prescott, E. C. (1982). Time to build and aggregate fluctuations. Econometrica, $50(6), 1345$.

Lucas, R. E. (1972). Expectations and the neutrality of money. Journal of Economic Theory, $4(2), 103$.

Lucas, R. (1976). Econometric policy evaluation: A critique. In K. Brunner \& A. Meltzer (Eds.), The Phillips curve and labor markets. Carnegie-Rochester Conference Series on Public Policy 1 (pp. 19-46). New York: American Elsevier.

Phillips, A. W. (1958). The relation between unemployment and the rate of change of money wage rates in the United Kingdom, 1861-1957. Economica, 25(100), 283-299.

Samuelson, P. A., \& Solow, R. (1960). Analytical aspects of anti-inflation policy: Papers and proceedings. American Economic Review, 50, 177-194.

Schulmeister, S. (2000). Globalization without global money: The double role of the dollar as national currency and as world currency. Journal of Post Keynesian Economics, 22(3), 365-395.

Schulmeister, S. (2008). On the manic-depressive fluctuations of speculative prices. In E. Hein, T. Niechoj, P. Spahn, \& A. Truger (Eds.), Finance-led capitalism. Marburg: Metropolis-Verlag. 
Schulmeister, S. (2014). European Governance - Do we need a new navigation map? Izmir Review of Social Sciences, 1(2), 1-36.

Schulmeister, S. (2018). Der Weg zur Prosperität. Salzburg: Ecowin.

Stigler, G. (1971). The theory of economic regulation. Bell Journal of Economics, 2(1), 3-21.

Walpen, B. (2004). Die offenen Feinde und ihre Gesellschaft: Eine hegemonietheoretische Studie zur Mont Pèlerin Society. Hamburg: VSA Verlag.

Open Access This chapter is licensed under the terms of the Creative Commons Attribution 4.0 International License (http://creativecommons.org/licenses/by/4.0/), which permits use, sharing, adaptation, distribution and reproduction in any medium or format, as long as you give appropriate credit to the original author(s) and the source, provide a link to the Creative Commons license and indicate if changes were made.

The images or other third party material in this chapter are included in the chapter's Creative Commons license, unless indicated otherwise in a credit line to the material. If material is not included in the chapter's Creative Commons license and your intended use is not permitted by statutory regulation or exceeds the permitted use, you will need to obtain permission directly from the copyright holder.

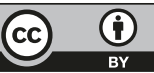

